1995

\title{
The Right to Choose How to Die: A Constitutional Analysis of State Laws Prohibiting Physician- Assisted Suicide
}

David Sloss

Santa Clara University School of Law, dlsloss@scu.edu

Follow this and additional works at: http://digitalcommons.law.scu.edu/facpubs

\section{Recommended Citation}

48 Stan. L. Rev. 937

This Article is brought to you for free and open access by the Faculty Scholarship at Santa Clara Law Digital Commons. It has been accepted for inclusion in Faculty Publications by an authorized administrator of Santa Clara Law Digital Commons. For more information, please contact sculawlibrarian@gmail.com. 


\title{
The Right To Choose How To Die: A Constitutional Analysis of State Laws Prohibiting Physician-Assisted Suicide
}

\author{
David L. Sloss*
}

Physician-assisted suicide (PAE) is an emotionally charged issue that state legislators struggle with more and more each year. In this note, David Sloss examines whether the right to voluntary PAE is protected by the Due Process Clause of the Fourteenth Amendment. Mr. Sloss argues that all competent, terminally ill patients have a fundamental right to die with dignity. $\mathrm{He}$ concludes that no state should place a substantial obstacle, or undue burden, in the path of a competent patient with an objectively rational desire to die.

I. InTRODUCTION .................................. 938

II. The Right To Refuse Life-Sustaining Medical Treatment ... 941

A. Is the Right To Refuse Unwanted Medical Treatment a Fundamental Right?

B. Is that Fundamental Right Broad Enough To Encompass the Right of a Competent Terminally Ill Patient To Refuse LifeSustaining Medical Treatment? ...................... 943

C. A Critique of Justice Scalia's View of Fundamental Rights ... 947

D. Refusal of Treatment and PAE ......................... 949

III. The Right to Physician-Assisted SuICIDE............... 950

A. The Liberty Interests at Stake: The Right To Choose How To Die ........................................ 951

1. Patients who are dependent upon artificial life support ... 952

2. Patients who are not dependent upon artificial life support........................................ 953

3. Comparing the two classes of patients .............. 954

B. Artificial Versus Natural PAE: Ethical Considerations ....... 955

1. The pro-life analysis .......................... 955

2. The pro-choice analysis ....................... 957

3. Kenneth Bergstedt-a hard case ................. 958

C. Artificial Versus Natural Euthanasia: A Comparative Risk

Analysis ........................................ 961

1. Competent $v$ s. incompetent...................... 961

* Third-year law student, Stanford Law School. M.P.P. Harvard University, 1983. B.A. Hampshire College, 1981. I wish to thank Professor Gerald Gunther for supervising this project, Professor Thomas Grey for helpful comments on an earlier draft of this note, and the editorial staff of the Stanford Law Review for their invaluable assistance. I also wish to thank my wife, Heidi BK Sloss, who has supported me in countless ways through three years of law school. 
2. Voluntary vs. involuntary ..................... 962

IV. The Permissible Scope of State Regulation .............. 963

A. Limiting the Class of Eligible People ................... 964

1. Competent.................................... 964

2. Voluntary................................. 965

3. Incurable and irreversible ....................... 966

4. Short life expectancy .......................... 968

B. Other Issues.................................... 970

1. Prescribing vs. administering ..................... 970

2. Assisted suicide by nonphysicians ................. 971

V. Conclusion ................................... 972

\section{INTRODUCTION}

Claire Renan was a ninety-year-old woman suffering from cancer of the rectum. ${ }^{1}$ Determined to die, she asked her physician to prescribe death-inducing medication. ${ }^{2}$ The physician refused and instead referred her for two psychiatric examinations. Both psychiatrists concurred that Mrs. Renan "was not truly depressed, but rather was reacting logically, albeit dramatically, to what was, for her, an unendurable existence." 3 Unable to care for herself, Mrs. Renan reluctantly agreed to enter a nursing home. Mrs. Renan's physician described her patient's plight:

When she was awake, she asked incessantly when the end would come. She accused me of abandoning her because I said I would not and could not give her a lethal injection. She inveighed against the staff at the nursing home for being insufficiently caring because nothing they did relieved her suffering. ... She finally died, after months of gradual blood loss and minimal nourishment $\ldots 4^{4}$

Jane Doe, a retarded thirty-three-year-old woman in a persistent vegetative state, had been mentally retarded since infancy. 5 She suffered from a progressive and incurable disorder of the central nervous system. ${ }^{6}$ Doe's guardian petitioned the court to authorize removing the tube which had provided Doe artificial hydration and nutrition for eight years. ${ }^{7}$ As long as the tube remained in place, the prognosis was for "an indefinite continuation of Doe's persistent vegetative state." 8 If the tube were removed, "then [Doe] would likely die of dehydration in a matter of days.' "9 The court granted the guardian's request to remove the feeding tube, reasoning that Doe would have requested withdrawal of treatment if she were competent. ${ }^{10}$

1. See Muriel R. Gillick, Choosing Medical Care in Old Age: What Kind, How Much, WHEN TO STOP 82 (1994).

2. Id. at 86 .

3. Id.

4. Id. at 87 .

5. Guardianship of Doe, 583 N.E.2d 1263, 1266 (Mass. 1992).

6. Id. at 1266 .

7. Id. at $1265-66$.

8. Id. at 1269.

9. Id.

10. Id. at 1272. 
Although Jane Doe was never legally competent, and had never expressed a desire to die, the law allowed her doctors to end her life. By contrast, even though Claire Renan was legally competent and repeatedly expressed a desire for her physician to help her die with dignity, the law prohibited her doctor from helping to end her life. Of course the law must limit the extent to which physicians may act to hasten a patient's death, but should the law define those limits to permit involuntary physician-assisted euthanasia of incompetent, nonterminal patients, such as Jane Doe, while prohibiting voluntary physicianassisted euthanasia for competent, terminally ill patients, such as Claire Renan? ${ }^{11}$

While some may contend that removing a feeding tube is not physicianassisted euthanasia, this note uses the term "physician-assisted euthanasia" (PAE) to refer both to acts that hasten death by providing an artificial deathinducing agent ("artificial PAE"), and to acts that hasten death by withholding or withdrawing artificial life-sustaining medical treatment ("natural PAE").12 The term "physician-assisted suicide" is a synonym for artificial PAE. ${ }^{13}$

Scholarly journals have recently published numerous commentaries, both for $^{14}$ and against ${ }^{15}$ physician-assisted suicide. Often, these commentaries as-

11. This note uses the term "voluntary euthanasia" to refer to assistance provided to a rational, competent adult who makes a considered choice to end his life. The term "involuntary euthanasia" refers to a choice made by a surrogate decisionmaker to end the life of an incompetent person. A grey area exists between the two extremes, for example, if a now incompetent person, when previously competent, expressed an unwritten, ill-defined wish not to be kept alive if she ever entered a permanent vegetative state.

12. For a justification of the view that withdrawal of life-sustaining medical treatment does constitute physician-assisted euthanasia, see notes 71-73 infra and accompanying text.

13. Some commentators use the term "assisted suicide" to refer to cases where the individual who seeks death performs the last act resulting in death, and the term "voluntary euthanasia" to refer to cases where someone else performs the last act resulting in death. See, e.g., Yale Kamisar, Are Laws against Assisted Suicide Unconstitutional?, HAstings CENTER REPORT May-June 1993, at 32, 35. One problem with this terminology is that, in common parlance, "physician-assisted suicide" refers only to acts that end life by means of a death-inducing agent, and not to acts that induce death by withdrawing artificial life support. Hence, this note uses the term "physician-assisted suicide" as a synonym for "artificial PAE," and uses the term "PAE" generically to include all forms of physician-aided dying, whether artificial or natural, voluntary or involuntary.

14. See, e.g., Joan W. Dalbey Donahue, Note, Physician-Assisted Suicide: A "Right" Reserved for Only the Competent?, 19 VT. L. REV. 795 (1995) (arguing that incompetent individuals retain the right to choose to end their lives, but that only the person who has executed an advanced-directive prior to becoming incompetent has an adequate means of effectuating that right); Dr. G. Steven Neeley, The Constitutional Right to Suicide, the Quality of Life, and the "Slippery-Slope": An Explicit Reply to Lingering Concerns, 28 AKRON L. REv. 53, 76 (1994) (arguing that competent adults should be allowed to solicit the assistance of others in order to make death as dignified as possible); john a. powell \& Adam S. Cohen, The Right to Die, 10 Issues L. \& MED. 169 (1994) (arguing that courts have been "too willing to allow an individual's desire to end her life to be outweighed by other considerations or by onerous burdens of proof"); Kathryn L. Tucker \& David J. Burman, Physician Aid in Dying: A Humane Option, a Constitutionally Protected Choice, 18 SEATTLE UnIv. L. Rev. 495, 508 (1995) (concluding that "[t]he Fourteenth Amendment protects the liberty to choose between a tortured, hideous death and a less painful, more dignified one, and it protects the equality of all who seek to make that fundamental, personal choice"); Note, Physician-Assisted Suicide and the Right to Die with Assistance, 105 HARv. L. REv. 2021, 2023 (1992) [hereinafter "Harvard Note"] (arguing that "a balancing test is the best doctrinal approach for determining the scope of the right to die with assistance").

15. See, e.g., Robert A. Destro, The Scope of the Fourteenth Amendment Liberty Interest: Does the Constitution Encompass a Right to Define Oneself out of Existence?: An Exchange of Views with john a. powell, Legal Director, American Civil Liberties Union, 10 IssUES L. \& MED. 183, 186 (1994) 
sume that PAE is illegal throughout the United States. In fact, every state in the United States permits "natural" PAE.16 States prohibit only "artificial" PAE.

Current law relies heavily on the distinction between artificial and natural PAE, and accords little weight to the distinction between voluntary and involuntary PAE. Thus, judges have disallowed voluntary, artificial PAE for competent, terminally ill patients such as Claire Renan, ${ }^{17}$ but have allowed involuntary, natural PAE for incompetent, nonterminal patients such as Jane Doe. ${ }^{18}$ Should there be a blanket approval for natural PAE, and an outright ban on artificial PAE, without distinguishing between voluntary and involuntary euthanasia, competent and incompetent patients, or terminal and nonterminal patients?

This note considers whether state laws that prohibit voluntary physicianassisted suicide violate the Fourteenth Amendment Due Process Clause. ${ }^{19}$ Part II argues that competent, terminally ill patients have a fundamental right ${ }^{20}$ voluntarily to end their lives by refusing life-sustaining medical treatment, ${ }^{21}$ that is, a fundamental right to natural voluntary PAE.

(asserting that "the right to die does not exist as a matter of moral logic or constitutional theory"); Arthur J. Dyck, Beyond Theological Conflict in the Courts: The Issue of Assisted Suicide, 9 Notre Dame J.L. EтHICS \& Pus. PoL'Y 503 (1995) (arguing that there exist nontheological reasons for retaining laws against assisted suicide and euthanasia); Kamisar, supra note 13, at 37 (arguing that laws permitting suicide reveal that our "suicide permissive society" exhibits a disregard for life); Edward J. Larson, Seeking Compassion in Dying: The Washington State Law Against Assisted Suicide, 18 SEATtLE UnIv. L. REv. 509, 519 (1995) (concluding that there is an "insufficient constitutional basis to overrule [the] judgment of the people" that physician-assisted suicide should be banned); Thomas J. Marzen, "Out, Out Brief Candle": Constitutionally Prescribed Suicide for the Terminally Ill, 21 Hastings Consr. L.Q. 799, 803 (1994) (claiming that "the asserted liberty interest in assisted suicide has no historical basis and is not an implicit right under the Fourteenth Amendment's 'liberty' guarantee"); Nancy J. Osgood, Assisted Suicide and Older People-A Deadly Combination: Ethical Problems in Permitting Assisted Suicide, 10 Issues L. \& MED. 415, 418 (1995) (claiming that arguments in support of a right to assisted suicide for older people reveal a devaluation of old age); Willard C. Shih, Note, Assisted Suicide, the Due Process Clause and "Fidelity in Translation," 63 FordhaM L. Rev. 1245, 1246 (1995) (concluding that "because both suicide and assisted suicide were proscribed when the ratifiers adopted the Fourteenth Amendment there is no constitutional right to seek assisted suicide").

16. See notes 40-50 infra and accompanying text for a summary of statutory and case law establishing the right to refuse life-sustaining medical treatment.

17. See notes $74-82$ infra and accompanying text for a discussion of cases involving voluntary, artificial euthanasia.

18. For a discussion of judicial decisions permitting involuntary natural euthanasia, see notes 154156 infra and accompanying text.

19. The Due Process Clause provides that no State shall "deprive any person of life, liberty, or property, without due process of law." U.S. ConsT. amend XIV, $\$ 1$.

20. The Supreme Court has used the terms "fundamental rights" and "fundamental liberty interests" interchangeably to refer to those rights that merit heightened scrutiny under the Due Process Clause. This note uses the terms accordingly.

21. Advocates and critics of physician-assisted suicide agree that the right to physician-assisted suicide cannot qualify as fundamental unless the right to refuse life-sustaining treatment also qualifies as fundamental. The question whether the right to refuse life-sustaining treatment is fundamental remains unsettled, since the Supreme Court has not ruled on the issue. See notes 32-39 infra and accompanying text. Since I am unaware of commentaries that include a detailed analysis of this unsettled question, an extended discussion of this question is necessary to lay the groundwork for a constitutional analysis of physician-assisted suicide. 
Part III argues that all competent, terminally ill patients have a fundamental right to choose how to die, ${ }^{22}$ which includes a right to both natural and artificial voluntary PAE. This argument has three components. First, the liberty interests of competent, terminally ill patients who seek natural PAE are indistinguishable from the liberty interests of competent, terminally ill patients who seek artificial PAE; ${ }^{23}$ both share a fundamental interest in choosing how to die. Second, there is no significant ethical distinction between natural and artificial $\mathrm{PAE}$. Third, the risks associated with artificial PAE are no greater than the risks associated with natural PAE.

Part IV considers both who should be eligible to exercise the fundamental right to physician-assisted suicide, and the extent to which states may regulate the exercise of this fundamental right. This Part argues that the state may not place a substantial obstacle, or undue burden, in the path of a competent patient with an objectively rational desire to die who seeks voluntary PAE.

\section{The Right To Refuse Life-Sustaining Medical Treatment}

Though the Supreme Court has held that a competent person has a significant liberty interest in refusing unwanted medical treatment, ${ }^{24}$ difficult questions remain unsettled: (1) whether that liberty interest is sufficiently weighty to be deemed "fundamental," and if so, (2) whether that fundamental right is broad enough to encompass the right of a competent, terminally ill patient to refuse even life-sustaining medical treatment. ${ }^{25}$

\section{A. Is the Right To Refuse Unwanted Medical Treatment a Fundamental Right?}

Laws that infringe "fundamental" liberty interests merit heightened scrutiny under the Due Process Clause. A particular liberty interest will be deemed "fundamental" if the court concludes that the right is "deeply rooted in this

22. Deciding who precisely may exercise a fundamental right to choose how to die is a particularly difficult question. If such a fundamental right exists, then the state has an important interest in limiting the class of people eligible to exercise that right. Parts II and III.A of this note refer to members of the eligible class as "competent, terminally ill patients." Part III.B suggests that this class includes all competent patients with a subjective desire to die that is objectively rational. Part IV analyzes in greater detail the eligibility criteria.

23. This note uses the terms "artificial life support," "life-sustaining treatment," and "life-sustaining medical treatment" interchangeably.

24. Washington v, Harper, 494 U.S. 210, 221-22 (1990) ("respondent possesses a significant liberty interest in avoiding the unwanted administration of antipsychotic drugs under the Due Process Clause of the Fourteenth Amendment"); Winston v. Lee, 470 U.S. 753 (1985) (state may not compel robbery suspect to undergo surgery to remove bullet from chest, even though surgery might have produced incriminating evidence); Union Pac. Ry. Co. v. Botsford, 141 U.S. 250 (1891) (holding that in a civil action for personal injury, the court may not order plaintiff, without his or her consent, to submit to a surgical examination to assess the extent of the plaintiff's injuries).

25. Courts have held that the right to refuse life-sustaining medical treatment extends even to incompetent patients who are not terminally ill. See Cruzan v. Director, Mo. Dep't of Health, 497 U.S. 261 (1990); see also note 45 infra. Thus, the class of people eligible to refuse life-sustaining medical treatment contains a broader range of individuals than just competent, terminally ill patients. However, since the chief purpose in Part $I$ is to lay the groundwork for a discussion of physician-assisted suicide, Part II focuses on the rights of competent, terminally ill patients. 
Nation's history and tradition." 26 The right to refuse unwanted medical treatment is deeply rooted in this nation's history and tradition, specifically, in the common law tradition according every individual the legal right to control his own body. More than one hundred years ago, the Supreme Court stated: "No right is held more sacred, or is more carefully guarded, by the common law, than the right of every individual to the possession and control of his own person, free from all restraint or interference of others . ..."27 Similarly, while serving on the New York Court of Appeals, Justice Cardozo wrote: "Every human being of adult years and sound mind has a right to determine what shall be done with his own body ...."28 The common law accorded such primacy to an individual's right to control his own body that "even the touching of one person by another without consent and without legal justification was a battery."29

In the context of the doctor-patient relationship, the common law principle of control over one's own body manifested itself in the tort doctrine of informed consent. "Under the common law of torts, the right to refuse any medical treatment emerged from the doctrines of trespass and battery, which were applied to unauthorized touchings by a physician." 30 Moreover, at common law, a surgeon who performed an operation without his patient's consent was guilty of an intentional tort and was liable for damages. ${ }^{31}$

Thus, at common law, the basic right to control one's own body encompassed an explicit right to refuse unwanted medical treatment, as expressed in the doctrine of informed consent. Since the common law right to refuse unwanted medical treatment is deeply rooted in this nation's history and tradition, it clearly is a fundamental right.

26. Moore v. City of E. Cleveland, 431 U.S. 494, 503 (1977) (recognizing that the Constitution protects the sanctity of the family because of the historical and traditionally important role the family has played in American society). The Moore standard is a variant of Justice Cardozo's videly cited phrase: "so rooted in the traditions and conscience of our people as to be ranked as fundamental." Snyder v. Massachusetts, 291 U.S. 97, 105 (1934). There appears to be no substantive difference between these two formulations. The other standard frequently used to assess whether a particular right qualifies as fundamental is that it must be "implicit in the concept of ordered liberty." Palko v. Connecticut, 302 U.S. 319, 325 (1937) (noting that there is no fundamental right to a jury trial or to immunity from prosecution except as the result of an indictment). In this author's view, the Palko standard is more difficult to apply than the Snyder/Moore standard. Therefore, this note uses the SnyderMoore standard.

27. Botsford, 141 U.S. at 251.

28. Schloendorff v. Society of New York Hosp., 105 N.E. 92, 93 (N.Y. 1914), overruled by Bing v. Thunig, 143 N.E.2d 3 (N.Y. 1957).

29. Cruzan, 497 U.S. at 269.

30. Mills v. Rogers, 457 U.S. 291,294 n.4 (1982) (explaining that the Constitution recognizes that mental patients have a liberty interest in deciding for themselves whether to submit to drug therapy).

31. Schloendorff, 105 N.E. at 93. 


\section{B. Is that Fundamental Right Broad Enough To Encompass the Right of a Competent Terminally Ill Patient To Refuse Life-Sustaining Medical Treatment?}

In Cruzan v. Director, Missouri Department of Health, ${ }^{32}$ the Supreme Court did not decide whether the right to refuse life-sustaining medical treatment is fundamental. ${ }^{33}$ The Court assumed, for purposes of that case, that "the United States Constitution would grant a competent person a constitutionally protected right to refuse lifesaving hydration and nutrition." 34 The Court balanced the individual's right against the relevant state interests, ${ }^{35}$ and upheld a Missouri law requiring clear and convincing evidence of an incompetent patient's wishes before a third party could exercise on behalf of that patient her right to refuse lifesaving hydration and nutrition. ${ }^{36}$

The Court could have reached the same conclusion by holding that the right to refuse lifesaving hydration and nutrition is fundamental, and then applying an "undue burden" analysis. Under the undue burden standard, "a law which serves a valid purpose, one not designed to strike at the right itself," does not violate the Fourteenth Amendment even if the law "has the incidental effect of making it more difficult" to exercise the fundamental right at issue. ${ }^{37}$ In Cruzan, the Court emphasized that the Missouri law was not designed to strike at the right to refuse lifesaving hydration and nutrition. Rather, the Court said that "Missouri has in effect recognized that under certain circumstances a surrogate may act for the patient in electing to have hydration and nutrition withdrawn in such a way as to cause death." 38 The Court characterized the Missouri requirement for clear and convincing evidence as a "procedural safeguard" designed "to assure that the action of the surrogate conforms as best it may to the wishes expressed by the patient while competent."39 Thus, Missouri's evidentiary requirement should survive undue burden scrutiny, because the law is designed to protect the exercise of the patient's right, not to inhibit the exercise of that right. Therefore, the Court's holding in Cruzan is consistent with the view that a competent, terminally ill patient has a fundamental right to refuse life-sustaining medical treatment.

Since the seminal 1976 case of In re Quinlan ${ }^{40}$ eighteen state courts of last resort have decided thirty-one cases involving the right of patients with incur-

32. Cruzan, 497 U.S. at 261.

33. Four justices asserted that a competent, terminally ill adult has a fundamental right to refuse life-sustaining medical treatment. Id. at 304-08 (Brennan, J., dissenting) (joined by Justices Marshall and Blackmun); id. at 343 (Stevens, J., dissenting).

34. Id. at 279. The Cruzan Court spoke generally about the rights of competent adults, without distinguishing between the rights of a terminally ill patient and the rights of a patient with a nonterminal condition. This is attributable to the fact that Nancy Cruzan was not terminally ill; "[m]edical experts testified that she could live another thinty years." Id. at 266 n.1.

35. Id. at 279.

36. Id. at 280 .

37. Planned Parenthood of Southeastern Pa. v. Casey, 505 U.S. 833, 874 (1992) (emphasis added).

38. Cruzan, 497 U.S. at 280.

39. Id.

40. 355 A.2d 647 (N.J.), cert. denied sub nom. Garger v. New Jersey, 429 U.S. 922 (1976). 
able medical conditions to refuse life-sustaining medical treatment. ${ }^{41}$ Of those thirty-one cases, only four involved competent patients. In all four cases involving competent patients, the courts held that the right to refuse unwanted medical treatment encompasses a right to refuse life-sustaining medical treatment, and that the patient's right outweighs competing state interests, including the state's substantial interest in protecting life. ${ }^{42}$

State courts of last resort have decided twenty-seven cases involving incompetent patients with incurable medical conditions who sought to withhold or withdraw life-sustaining medical treatment. Seven of those cases involved incompetent patients who were never competent; ${ }^{43}$ the remaining twenty involved patients who had been previously competent. All twenty cases involving previously competent patients proceeded from the assumption that a competent patient's right to refuse life-sustaining medical treatment outweighs competing state interests. ${ }^{44}$ Despite this common assumption, these state courts of last resort did not all reach the same conclusions. In fifteen cases, courts ruled in favor of plaintiffs seeking to withhold or withdraw life-sustaining medical treatment from previously competent patients. ${ }^{45}$ In four cases,

41. See notes $42-46,154$ infra. State courts of last resort have also decided several refusal of treatment cases in which patients did not have incurable medical conditions. See, e.g., In re Dubreuil, 629 So. 2d 819 (Fla. 1993) (holding that a hospital's decision to administer blood transfusions to a patient against her wishes violated her constitutional rights of privacy and bodily self-determination); Public Health Trust of Dade County v. Wons, 541 So. 2d 96 (Fla. 1989) (holding that a competent adult has a constitutional right to refuse a blood transfusion on religious grounds); Norwood Hosp. v. Munoz, 564 N.E.2d 1017 (Mass. 1991) (stating that competent Jehovah's Witness adult has right to refuse lifesaving medical treatment); In re Brown, 478 So. $2 \mathrm{~d} 1033$ (Miss. 1985) (declaring that a state's interest in having an individual available for testimony at a criminal trial is not so compelling as to force the individual to accept blood transfusions against her will); Fosmire v. Nicoleau, 551 N.E.2d 77 (N.Y. 1990) (holding that a state's interest in preserving the life of a parent for the benefit of her child does not outweigh the parent's right to determine the course of her medical treatment and refuse transfusions); In $r e$ Milton, 505 N.E.2d 255 (Ohio) (providing that a state cannot compel a competent person to submit to medical treatment against her religious belief in faith healing), cert. denied, 484 U.S. 820 (1987). This note addresses only those cases involving patients with incurable medical conditions.

42. The Florida Supreme Court upheld the right of a competent 73-year-old man with Lou Gehrig's disease, whose life expectancy was less than six months, to remove a mechanical respirator, even though he was expected to die within one hour after its removal. Satz v. Perlmutter, 379 So. 2d 359 (Fla. 1980). The New Jersey Supreme Court upheld the right of a competent, terminally ill 37-yearold woman with Lou Gehrig's disease to remove a mechanical respirator. In re Farrell, 529 A.2d 404 (N.J. 1987). The Georgia Supreme Court upheld the right of a competent quadriplegic patient, who was not terminally ill but was incapable of spontaneous respiration, to remove a mechanical respirator. State v. McAfee, 385 S.E.2d 651 (Ga. 1989). Finally, the Supreme Court of Nevada upheld the right of a competent, nonterminal 31-year-old quadriplegic to remove a mechanical respirator, despite the fact that he would die very quickly after its removal. McKay v. Bergsted, 801 P.2d 617 (Nev. 1990).

43. For discussion of cases in which the patient was never competent, see notes 154-156 infra and accompanying text.

44. Notes $45-46$ infra list 19 of these 20 cases. The twentieth case is Severns v. Wilmington Medical Ctr., Inc., 421 A.2d 1334, 1350 (Del. 1980) (remanding case to Court of Chancery to obtain additional evidence before determining whether to grant plaintiff's request for removal of life support).

45. Rasmussen v. Fleming, 741 P.2d 674, 682-83 (Ariz. 1987); McConnell v. Beverly Enters.Conn., Inc., 553 A.2d 596 (Conn. 1989); In re Tavel, 661 A.2d 1061 (Del. 1995); Browning v. Herbert, 568 So. 2d 4 (Fla. 1990); John F. Kennedy Memorial Hosp., Inc. v. Bludworth, 452 So. 2d 921 (Fla. 1984); Estate of Longeway v. Community Convalescent Ctr., 549 N.E.2d 292 (Ill. 1989); DeGrella v. Elston, 858 S.W.2d 698 (Ky. 1993); Joseph v. Gardner, 534 A.2d 947 (Me. 1987); Brophy v. New England Sinai Hosp., Inc., 497 N.E.2d 626 (Mass. 1986); In re Spring, 405 N.E.2d 115 (Mass. 1980); In re Peter, 529 A.2d 419 (N.J. 1987); In re Jobes, 529 A.2d 434 (N.J. 1987); Soper v. Storar, 420 N.E.2d 
courts denied relief to plaintiffs seeking withdrawal of life-sustaining medical treatment from previously competent patients on the grounds that plaintiffs failed to prove that the patient, if competent, would have chosen to forego such treatment. ${ }^{46}$ Even so, all these state courts agree that a previously competent patient with an incurable medical condition has a right to refuse life-sustaining medical treatment that outweighs countervailing state interests, including the state's substantial interest in protecting life, provided that plaintiffs prove that the patient, if competent, would have chosen to forego such treatment. ${ }^{47}$

Although plaintiffs have litigated most cases involving refusal of life-sustaining medical treatment in state courts, federal district courts have decided three such cases. In all three cases, the courts ruled that the patient's right to refuse unwanted medical treatment was broad enough to encompass a right to refuse life-sustaining medical treatment, and that the patient's right was sufficiently weighty to overcome competing state interests. ${ }^{48}$

In addition to judicial decisions protecting the right of competent, terminally ill patients to refuse life-sustaining medical treatment, forty-seven states and the District of Columbia have enacted "living will" statutes, which authorize a competent patient to execute a declaration instructing his physician to withhold or withdraw life-sustaining medical treatment if the declarant is in a terminal condition and can no longer make medical decisions for himself. ${ }^{49}$

64 (N.Y.), cert. denied, 454 U.S. 858 (1981); In re Ingram, 689 P.2d 1363 (Wash. 1984); In re Colyer, 660 P.2d 738 (Wash. 1983).

46. Mack v. Mack, 618 A.2d 744 (Md. 1993); Cruzan v. Harmon, 760 S.W.2d 408 (Mo. 1988) (en banc); In re Conroy, 486 A.2d 1209 (N.J. 1985); In re Westchester County Medical Ctr., 531 N.E.2d 607 (N.Y. 1988).

47. The consensus of state courts of last resort on this point is consistent with the Supreme Court's holding in Cruzan that a state may require a third party to prove by clear and convincing evidence that a now incompetent patient would refuse lifesaving medical treatment before the third party can exercise the right of refusal on behalf of the patient. See notes 32-39 supra and accompanying text.

48. One case involved a competent patient with "graft-versus-host" disease, which he contracted as a result of a bone marrow transplant, who sought the removal of a mechanical respirator. Deel v. Syracuse Veterans Admin. Medical Ctr., 729 F. Supp. 231, 231 (N.D.N.Y. 1990). Another involved a previously competent patient in a persistent vegetative state whose husband sought the removal of a feeding tube. Gray v. Romeo, 697 F. Supp. 580 (D.R.I. 1988). The third involved a competent, 71year-old patient with terminal cancer who sought removal of a mechanical respirator. Tune v. Walter Reed Army Medical Hosp., 602 F. Supp. 1452 (D.D.C. 1985).

49. Ala. Code $\S \S 22-8 \mathrm{~A}-1$ to -10 (1990); Alaska Stat. $\$ \S 18.12 .010$ to -.100 (1994); Aruz. Rev. Stat. Ann. §§ 36-3201 to -3262 (1993 \& Supp. 1995); ARK. CODE ANn. §§ 20-17-201 to -217 (Michie 1991); Cal. Health \& Safety Code \$§ 7185-7194.5 (West Supp. 1996); Colo. Rev. Stat. AnN. §§ 15-18-101 to -113 (West 1989 \& Supp. 1995); Conn. Gen. Stat. AnN. §§ 19a-570 to -580c (West Supp. 1995); DeL. CODE ANN. tit. 16, §§ 2501-2509 (1995); D.C. CODE ANN. §§ 6-2421 to -2430 (1995); FLA. Stat. ANN. §§ 765.101-.401 (West Supp. 1995); GA. Code ANN. \$§ 31-32-1 to -12 (1991 \& Supp. 1995); Haw. Rev. StaT. §§ 327D-1 to 27 (1991 \& Supp. 1995); IDAHo CODE §§ 39-4501 to 4509 (1993); ILL. ANn. STAT. ch. 755, para. 35/1 to /10 (Smith-Hurd 1992); IND. CODE ANN. §§ 16-364-1 to -21 (West Supp. 1995); IOWA Code ANN. \$§ 144A.1-.12 (West 1989 \& Supp. 1995); KAN. STAT. ANN. $\S \S 65-28,101$ to $-28,109$ (1992 \& Supp. 1994); Ky. REv. Stat. ANn. §§ 311.621-.644 (Baldwin Supp. 1995); LA. Rev. Stat. AnN. §§ 40:1299.58.1-.10 (West 1992); ME. Rev. Stat. Ann. tit. 18-A, $\S \S 5-801$ to -817 (West Supp. 1995); MD. Code ANn. HEALTH-GEN. §§ 5-601 to -618 (1994 \& Supp. 1995); Minn. Stat. Ann. §§ 145B.01-.17 (West Supp. 1995); Miss. Code ANn. \$§ 41-41-101 to -121 (1993); Mo. Ann. Stat. \$§ 459.010-.055 (Vernon 1992); Mont. Code ANN. §§ 50-9-101 to -206 (1994); Neb. Rev. Stat. \$§ 20-401 to -416 (Supp. 1994); Nev. Rev. STAt. ANN. \$§ 449.535-.690 (Michie 1991 \& Supp. 1995); N.H. Rev. Stat. ANN. §§ 137-H:1 to :16 (1990 \& Supp. 1995); N.J. Stat. Ann. $\S \S 26: 2 H-53$ to -78 (West Supp. 1995); N.M. Stat. AnN. $\$ \$ 24-7-1$ to -10 (Michie 1995); 
Sixteen of these living will statutes include language substantially identical to the following: "The legislature finds that adult persons have the fundamental right to control the decisions relating to the rendering of their own medical care, including the decision to have life-sustaining procedures withheld or withdrawn in instances of a terminal condition." 50

Although the right to refuse life-sustaining medical treatment lacks the long common law tradition associated with the right to refuse medical treatment more generally, the Supreme Court recognizes that the scope of fundamental rights is continually evolving. For example, in delimiting the scope of fundamental rights, Justice Harlan observed that the Court must strike a balance between respect for individual liberty and "the demands of organized society." 51 He added:

The balance of which I speak is the balance struck by this country, having regard to what history teaches are the traditions from which it developed as well as the traditions from which it broke. That tradition is a living thing. A decision of this Court which radically departs from it could not long survive, while a decision which builds on what has survived is likely to be sound. ${ }^{52}$

The common law right to refuse unwanted medical treatment is a right "deeply rooted in this Nation's history and tradition." 53 This tradition is a living thing. Decisions by state and federal courts, and statutory enactments by state legislatures, have expanded the traditional common law right to encompass the right

N.C. Gen. Stat. §§ 90-320 to -322 (1993); N.D. Centr. Code §§ 23-06.4-01 to -14 (1991 \& Supp. 1995); Ohio Rev. Code ANN. §§ 2133.01-.15 (Anderson 1994 \& Supp. 1994); OKLA. STAT. ANN. tit. 63, §§ 3101.1-3101.16 (West Supp. 1996); OR. Rev. STAT. $\S \S 127.605-.660$ (1990 \& Supp. 1994); 20

Pa. Cons. Stat. AnN. §§ 5401-5416 (Supp. 1995); R.I. Gen. Laws §§ 23-4.11-1 to -14 (Supp. 1995); S.C. Code ANN. $\S \S 44-77-10$ to -160 (Law. Co-op. Supp. 1995); S.D. Codified Laws ANn. \$§ 34-12D1 to -22 (1994); Tenn. Code ANN. \$§ 32-11-101 to -112 (Supp. 1995); Tex. Health \& SAFETY Code ANN. \$§ 672.001-.021 (West 1992 \& Supp. 1996); UTAH CODE ANN. §§ 75-2-1101 to -1119 (1993 \& Supp. 1995); VT. Srat. AnN, tit. 18, §§ 52S1-5262 (1987); VA. Code ANN. \$§ 54.1-2981 to -2993 (Michie 1994); WASh. Rev. CODE ANN. \$\$ 70.122.010-.920 (West 1992 \& Supp. 1996); W. VA. Code $\S \S 16-30-1$ to -13 (1995); Wis. Stat. AnN. $\$ \$ 154.01-.15$ (West $1989 \&$ Supp. 1995); Wyo. Stat. $\S \S 35-22-101$ to -109 (1994).

The only states that have not enacted living will statutes are New York, Massachusetts, and Michigan. All three have, however, enacted health care proxy provisions that enable a competent adult to delegate authority to another person to make health care decisions, including the refusal or withdrawal of life-sustaining treatment, on his behalf. Mass. ANn. Laws ch. 201D, § 1-17 (Law. Co-op. 1994); Mich. Stat. Ann. § 27.5496 (Callaghan 1992); N.Y. Pub. Health Law \$\$ 2980-2994 (McKinney 1993 \& Supp. 1996). Many of the states that have adopted living will statutes also authorize appointment of a health care proxy or surrogate.

50. AlA. CODE § 22-8A-2 (1990) (emphasis added). Other state codes that identify the right to refuse life-sustaining medical treatment as a fundamental right include: CAL. HEALTH \& SAFETY CODE $\S 7185.5$ (West Supp. 1996); Colo. Rev. Stat. AnN. \& 15-18.5-101 (West Supp. 1995); Fla. Stat. ANN. § 765.102 (West Supp. 1995); Haw. Rev. STAT. § 327D-1 (1991); IDAmo Code § 39-4502 (1993); Iru. AnN. Stat. ch. 755, para. 35/1 (Smith-Hurd 1992); Kan. Stat. ANN. § 65-28,101 (1992); La. Rev. Stat. Ann. § 40:1299.58.1 (West 1992); Neb. Rev. Stat. § 20-402 (Supp. 1994); N.J. Stat. AnN. § 26:2H-54 (West Supp. 1995); N.C. Gen. Stat. § 90-320 (1993); R.I. Gen. Laws § 23-4.11-1 (Supp. 1995); TeNn. Code ANN. § 32-11-102 (Supp. 1995); Vt. Stat. ANN. tit. 18, § 5251 (1987); WASH. Rev. CODE ANN. $\$ 70.122 .010$ (West Supp. 1996).

51. Poe v. Ullman, 367 U.S. 497, 542 (1961) (Harlan, J., dissenting).

52. Id.

53. Moore v. City of E. Cleveland, 431 U.S. 494, 503 (1977) (discussing fundamental rights in the context of family sanctity). 
of a competent, terminally ill patient to refuse life-sustaining medical treatment. Moreover, every federal court and state court of last resort that has considered the issue agrees that the right of a competent, terminally ill patient to refuse life-sustaining medical treatment outweighs countervailing state interests, including the state's substantial interest in protecting life. ${ }^{54}$ Hence, the right of a competent, terminally ill patient to refuse life-sustaining medical treatment qualifies as fundamental. Indeed, given the unanimity of views among state legislatures and state and federal courts, a decision by the Supreme Court holding that this right is not fundamental "could not long survive," 55 whereas a holding that recognizes and builds on state and federal court decisions and state legislative enactments "is likely to be sound."56

\section{A Critique of Justice Scalia's View of Fundamental Rights}

In contrast to Justice Harlan's concept of a living tradition, Justice Scalia has proposed a bright-line rule for determining whether a particular right qualifies as fundamental: If there is no deeply rooted tradition of laws protecting a right, that right cannot be fundamental.57 Applying this rule to the refusal of life-sustaining treatment, one could argue that the right of a competent, terminally ill patient to refuse life-sustaining medical treatment cannot qualify as a fundamental right, because artificial life-support measures are too recent an invention for there to be a deeply rooted tradition of laws protecting the right to refuse such measures. ${ }^{58}$

This argument hinges on two assumptions: (1) that one must describe the right at issue in the narrowest possible terms ${ }^{59}$-e.g., as a right to refuse lifesustaining medical treatment, rather than a right to refuse medical treatment in general; and (2) that a tradition must date back to at least the nineteenth century, when the Fourteenth Amendment was ratified, to qualify as deeply rooted. ${ }^{60}$ Both assumptions are essential to the argument, because there is a

54. See notes 40-48 supra and accompanying text.

55. Poe, 367 U.S. at 542 (Harlan, J., dissenting).

56. Id.

57. Justice Scalia has stated: "It is at least true that no 'substantive due process' claim can be maintained unless the claimant demonstrates that the State has deprived him of a right historically and traditionally protected against state interference." Cruzan v. Director, Mo. Dep't of Health, 497 U.S. 261, 294 (1990) (Scalia, J., concurring).

58. Although Justice Scalia articulated his proposed bright-line rule in Cruzan, he did not make this particular argument in Cruzan.

59. Justice Scalia argues this point explicitly in Michael H. v. Gerald D., 491 U.S. 110, 127 n.6 (1989) (plurality opinion) ("We refer to the most specific level at which a relevant tradition protecting, or denying protection to, the asserted right can be identified.").

60. I am not aware of any opinion in which Justice Scalia has made this assumption explicit, but in several of his opinions it is implicit. See, e.g., Cruzan, 497 U.S. at 294-95 (Scalia, J., concurring) (arguing that a right to suicide cannot be fundamental, because assisted suicide was generally outlawed at the time the Fourteenth Amendment was adopted); Michael H., 491 U.S. at 125 (plurality opinion) ("Since it is [petitioner's] burden to establish that ... a power ... is so deeply embedded within our traditions as to be ... fundamental," the absence of such power under English and early U.S. common law "alone might defeat his case."). Compare Bowers v. Hardwick, 478 U.S. 186, 192-94 (1986), in which Justice White, writing for the Court, analyzed the prohibition of homosexual sodomy in a similar manner-noting the "ancient roots" of proscription against homosexual sodomy and tracing its criminalization in 32 states throughout the 19th century. 
pre-nineteenth century legal tradition recognizing the general right to refuse medical treatment, ${ }^{61}$ and there is a twentieth century legal tradition that recognizes the specific right of a competent, terminally ill patient to refuse life-sustaining medical treatment. ${ }^{62}$ In short, this argument can succeed only if one limits the scope of fundamental rights to those specific rights (narrowly defined) that were accorded positive legal protection in the nineteenth century.

But the Supreme Court has consistently rejected this stagnant view of substantive due process. ${ }^{63}$ In the words of Justice Frankfurter:

The Due Process Clause places upon this Court the duty of exercising a judgment....

... To believe that this judicial exercise of judgment could be avoided by freezing "due process of law" at some fixed stage of time or thought is to suggest that the most important aspect of constitutional adjudication is a function for inanimate machines and not for judges ... .64

In keeping with this more expansive view of the scope of fundamental rights, the Supreme Court in Planned Parenthood of Southeastern Pennsylvania $v$. Casey explicitly rejected Justice Scalia's proposed rule, arguing that this rule is inconsistent with numerous Supreme Court decisions. The Casey joint opinion explained: "It is . . . tempting . . . to suppose that the Due Process Clause protects only those practices, defined at the most specific level, that were protected against government interference by other rules of law when the Fourteenth Amendment was ratified. ... But such a view would be inconsistent with our law."65

Justice Scalia has proposed another variant of the bright-line rule for determining whether a particular right qualifies as fundamental: If there is a deeply rooted tradition of laws denying a right, then that right cannot be fundamental. ${ }^{66}$ Applying this rule in Cruzan, Justice Scalia argued that the asserted right to refuse life-sustaining medical treatment could not qualify as fundamental, because there is a deeply rooted tradition of laws prohibiting assisted suicide. ${ }^{67}$

61. See notes 26-31 supra and accompanying text.

62. See notes 40-50 supra and accompanying text.

63. However, a few Supreme Court decisions have adopted Justice Scalia's narrow view of the scope of fundamental rights. E.g., Bowers, 478 U.S. at 186 (focusing on "homosexual sodomy" rather than "consensual sexual activity"); Michael H., 491 U.S. at 127 n.6 (plurality opinion) (focusing upon "the societal tradition regarding the natural father's rights vis-á-vis a child whose mother is married to another man," rather than upon "parenthood" rights in general). However, these decisions depart from the dominant trend of recent substantive due process jurisprudence, best exemplified by the joint opinion in Planned Parenthood of Southeastern Pennsylvania v. Casey, 505 U.S. 833 (1992).

64. Rochin v. California, 342 U.S. 165, 171 (1952).

65. Casey, 505 U.S. at 847. The Casey joint opinion asserts that the following Supreme Court decisions are inconsistent with Justice Scalia's proposed rule: Loving v. Virginia, 388 U.S. 1 (1967); Tumer v. Safley, 482 U.S. 78 (1987); Carey v. Population Services International, 431 U.S. 678 (1977); Griswold v. Connecticut, 381 U.S. 479 (1965); Pierce v. Society of Sisters, 268 U.S. 510 (1925); and Meyer v. Nebraska, 262 U.S. 390 (1923). Id.

66. According to Justice Scalia: "The protection need not take the form of an explicit constitutional provision or statutory guarantee, but it must at least exclude . . . a societal tradition of enacting laws denying the interest." Michael H., 491 U.S. at 122 n.2 (plurality opinion).

67. Cruzan v. Director, Mo. Dep't of Health, 497 U.S. 261, 294-95 (1990) (Scalia, J., concurring) (tracing the criminalization of attempted and assisted suicide from English common law through 50 years following the ratification of the Fourteenth Amendment). 
This argument fails to recognize the important qualitative and quantitative distinctions between a terminally ill patient's refusal of life-sustaining medical treatment and a physically healthy, but depressed, individual's decision to end his life. The quantitative distinction is that the terminally ill patient has a fairly short life expectancy, 68 whereas the depressed person might have a life expectancy of several decades. The qualitative distinction is that the terminally ill patient's condition is incurable, ${ }^{69}$ whereas the depressed person could potentially be cured. A vast majority of state legislatures recognize the quantitative and qualitative differences between suicide and refusal of life-sustaining treatment. More than forty states and the District of Columbia specify in their living will statutes that death resulting from the refusal of life-sustaining medical treatment in accordance with the statute does not constitute suicide. ${ }^{70}$ Thus, the deeply rooted tradition of laws prohibiting assisted suicide does not apply to refusal of life-sustaining medical treatment. And because there is no deeply rooted tradition of laws denying the right of a competent, terminally ill patient to refuse life-sustaining medical treatment, Justice Scalia's proposed bright-line rule does not invalidate the claim that a competent, terminally ill patient has a fundamental right to refuse life-sustaining treatment.

\section{Refusal of Treatment and PAE}

What are the implications of the fundamental right to refuse life-sustaining treatment for PAE? Euthanasia is defined as "the act of putting to death painlessly or allowing to die, as by withholding extreme medical measures, a person or animal suffering from an incurable, esp[ecially] a painful, disease or condition."71 Hence, physician assistance in allowing a terminally ill patient to die by withholding or withdrawing life-sustaining treatment clearly qualifies as "physician-assisted euthanasia."

In this note, the term "natural" PAE describes the withholding or withdrawal of artificial life-sustaining medical treatment, ${ }^{72}$ while the terms "artifi-

68. Most states' living will statutes include the element of a short life expectancy in their definitions of "terminal condition." See, e.g., CAL. Health \& SAFETY Code § 7186(j) (West Supp. 1996) (" 'Terminal condition' means an incurable and irreversible condition that without the administration of life-sustaining treatment, will, within reasonable medical judgment, result in death within a relatively short time.").

69. Most states' living will statutes include the element of incurability in their definitions of "terminal condition." See, e.g., id.

70. See, e.g., CAl. Health \& SAfETy Code $\$ 7191.5$ (a) (West Supp. 1996) ("Death resulting from the withholding or withdrawal of a life-sustaining treatment in accordance with this chapter does not constitute, for any purpose, a suicide ...."). Only five state living will statutes lack such explicit statutory provisions: CONN. GEN. Stat. ANN. \$§ 19a-570 to -580c (West Supp. 1995); IDAHo CODE $\S \S 39-4501$ to -4509 (1993); Mo. ANN. Stat. $\$ \$ 459.010-.055$ (Vernon 1992); Or. Rev. Stat. $\S \S 127.605-.660$ (1990 \& Supp. 1994); WYo. STAT. $\S \S 35-22-101$ to -109 (1994).

71. RANDOM House DictionarY OF THE ENGLISH LANGUAGE 670 (2d. ed. unabridged 1987); see also BLACk's LAW Dictionary 554 (6th ed. 1990) (defining euthanasia as "[t]he act or practice of painlessly putting to death persons suffering from incurable and distressing disease as an act of mercy"). This altemative definition is incomplete because it addresses only "putting to death," not "allowing to die."

72. A death resulting from refusal of life-sustaining medical treatment is "natural," in the sense that life-sustaining medical treatment artificially prolongs life. 
cial" PAE and "physician-assisted suicide" describe the act of providing or administering an artificial death-inducing agent. ${ }^{73}$ Given this terminology, a fundamental right to refuse life-sustaining treatment can also be described as a fundamental right to natural PAE. In Part III, this note argues that a competent, terminally ill patient's fundamental rights under the Fourteenth Amendment embrace the right not only to natural PAE, but also to physician-assisted suicide or artificial PAE.

\section{The Right to Physician-Assisted Suicide}

In the past two years, two federal district courts, ${ }^{74}$ two federal appeals courts, ${ }^{75}$ and one state supreme court ${ }^{76}$ have addressed the constitutionality of state laws prohibiting physician-assisted suicide. ${ }^{77}$ In Compassion in Dying $v$. Washington, a federal district court held that a competent, terminally ill adult has a fundamental right, protected by the Fourteenth Amendment, voluntarily to hasten his death by ingesting a lethal dose of medication. ${ }^{78}$ The Ninth Circuit affirmed, holding that "a liberty interest exists in the choice of how and when one dies, and that the provision of the Washington statute banning assisted suicide, as applied to competent, terminally ill adults who wish to hasten their deaths by obtaining medication prescribed by their doctors, violates the Due Process Clause."79 In Quill v. Koppell, a federal district court upheld the constitutionality of New York statutes that penalize assisted suicide. ${ }^{80}$ The Second Circuit reversed, holding that "the statutes lack any rational basis and are violative of the Equal Protection Clause. ${ }^{81}$ Finally, in People v. Kevorkian, the Michigan Supreme Court held, in a divided opinion, that Dr. Jack Kevor-

73. A death resulting from lethal medication is "artificial," in the sense that lethal medication is an artificial agent that hastens death.

74. Compassion in Dying v. Washington, 850 F. Supp. 1454 (W.D. Wash. 1994), rev'd, 49 F.3d 586 (9th Cir. 1995), reh'g en banc granted, 62 F.3d 299 (9th Cir. 1995), aff'd on reh'g, No. 94-35534, 1996 WL 94848 (9th Cir. Mar. 6, 1996) (en banc); Quill v. Koppell, 870 F. Supp. 78 (S.D.N.Y. 1994), rev'd, Quill v. Vacco, No. 95-7028, 1996 WL 148605 (2d Cir. Apr. 2, 1996).

75. Compassion in Dying v. Washington, No. 94-35534, 1996 WL 94848 (9th Cir. Mar. 6, 1996) (en banc); Quill v. Vacco, No. 95-7028, 1996 WL 148605 (2d Cir. Apr. 2, 1996).

76. People v. Kevorkian, 527 N.W.2d 714 (Mich. 1994), cert. denied, 115 S. Ct. 1795 (1995) (denying petition from Dr. Kevorkian), and cert. denied sub nom. Hobbins v. Kelley, 115 S. Ct. 1795 (1995) (denying petition from Dr. Kevorkian's patients).

77. In November 1994, Oregon voters approved the Oregon Death with Dignity Act, which would allow doctors to prescribe a lethal dose of medication to terminally ill adult Oregon residents who choose voluntarily to end their lives in a "humane and dignified manner." Measure 16, Oregon Death With Dignity Act, [hereinafter Oregon Act], reprinted in Kathy T. Graham, Last Rights: Oregon's New Death with Dignity Act, 31 WiLlaMETTE L. REv. 601, 637-46 (1995). A federal district court recently held that the Oregon Act violates the Equal Protection Clause, because there is no rational relationship between the legislative distinction between terminal and nonterminal patients and the state's interest in permitting assisted suicide. Lee v. Oregon, 891 F. Supp. 1429, 1437 (D. Or. 1995).

78. $850 \mathrm{~F}$. Supp. at 1462 ("“ $[\mathrm{A}]$ competent, terminally ill adult has a constitutionally guaranteed right under the Fourteenth Amendment to commit physician-assisted suicide.").

79. Compassion in Dying, 1996 WL 94848 at 39 (9th Cir.) (en banc). Prior to the en banc decision, a three-judge panel had voted to reverse the District Court decision. 49 F.3d 586 (1995).

80. 870 F. Supp. 78, 84 (S.D.N.Y. 1994).

81. Quill, 1996 WL 148605 at 11. 
kian's patients lacked a constitutionally protected right to obtain physician assistance in acting affirmatively to end their lives. ${ }^{82}$

This Part analyzes the issues these cases raise. The analysis is divided into three sections. The first section argues that the liberty interests of competent, terminally ill patients who are dependent upon artificial life support and who seek natural PAE are indistinguishable from the liberty interests of competent, terminally ill patients who are not dependent upon artificial life support and who seek artificial PAE;83 both classes share a fundamental interest in choosing how to die. The next section contends that, within the class of competent patients who seek PAE, there is no significant ethical distinction between those who seek natural versus artificial PAE, but there is a significant ethical distinction between those whose desire to die is objectively rational, and those whose desire to die is not objectively rational. ${ }^{84}$ The final section argues that artificial PAE poses no greater risk to competent patients than natural PAE, and, in fact, poses fewer risks to incompetent patients than natural PAE. This Part concludes that all competent patients who have a subjective desire to die that is objectively rational have a fundamental right to choose how to die, a right that encompasses both natural and artificial PAE.

\section{A. The Liberty Interests at Stake: The Right To Choose How To Die}

A leading medical commentator on death and dying says that faith in the possibility of a good death "has ever been a tradition of Western societies, which in centuries past valued a good death as the salvation of the soul .... The good death has increasingly become a myth .... The chief ingredient of the myth is the longed-for ideal of 'death with dignity.' "85 The ideal of death with dignity is "mythic" in two senses. First, the reality of death often falls short of the ideal. Second, and more important, the desire for death with dignity is a powerful psychological drive that, consciously or unconsciously, motivates many individuals in Western societies who face impending death. ${ }^{86}$

82. Kevorkian, 527 N.W.2d at 733 ("[T]he right to commit suicide is neither implicit in the concept of ordered liberty nor deeply rooted in this nation's history and tradition. It would be an impermissibly radical departure from existing tradition .... to declare that there is such a fundamental right protected by the Due Process Clause."). The Michigan Supreme Court issued a single opinion governing four separate cases pertaining to Doctor Kevorkian's efforts to assist persons who wished to end their lives. While the Michigan Supreme Court opinion does not make clear whether all of the individuals were terminally ill, at least one of the challengers to the Michigan law prohibiting assisted suicide was terminally ill. Hobbins v. Attorney Gen., 518 N.W.2d 487, 489 (Mich. Ct. App. 1994).

83. In Compassion in Dying, Court of Appeals Judge Noonan argues that the two classes of patients are distinguishable: "The district court found itself unable to distinguish between a patient refusing life support and a patient seeking medical help to bring about death .... Whatever difficulty the district court experienced in distinguishing one situation from the other, it was not experienced by the majority in Cruzan." Compassion in Dying, 49 F.3d at 591. The appropriate constitutional inquiry, though, is not whether the two classes of patients are distinguishable (which they are) but whether their liberty interests are distinguishable. See text accompanying notes 85-107 infra.

84. See text accompanying notes 117-127 infra.

85. Sherwin B. Nuland, How we Die: Rerlections on Life's Final Chapter at xvi (1994).

86. The power of the death with dignity ideal is evidenced by the widespread appeal of popular books on the subject that have been published in recent years. E.g., Norman L. Cantor, AdvancE Directives and the Pursuit of Death with Dignity (1993); Donald W. Cox, Hemilock's Cup: The Struggle for DeATH with DigntTy (1993); Derex Humphry, Dying with Dignity: Understanding 
Competent, terminally ill patients who seek natural PAE and those who seek artificial PAE share a common interest in choosing how to die, an interest that is often characterized as an interest in death with dignity.

\section{Patients who are dependent upon artificial life support.}

Martha Tune was a seventy-one-year-old patient with terminal cancer. ${ }^{87}$ She was attached to a respirator, "without which she would "immediately experience respiratory arrest and death." "88 She petitioned the court "to remove the artificial life support from her . . . to permit her to die with dignity."89 Thus, Ms. Tune asserted that she had a liberty interest in choosing how to die; she wanted to die with dignity. From her perspective, removal of the respirator constituted a means to that end. By granting her request to withdraw life support, the court recognized her right to choose how to die.

Larry McAfee was a competent, quadriplegic adult who could not breathe without a ventilator. He sought a court order authorizing removal of his ventilator and administration of a sedative by a medical professional. ${ }^{90} \mathrm{Mr}$. McAfee had "devised a means of turning off the ventilator himself by way of a timer"1 but had refrained from doing so "due to the severe pain he suffer[ed] when deprived of oxygen." 92 Thus, Larry McAfee could have killed himself without medical assistance, but it would have been a very painful death. He sought medical assistance, in the form of a sedative, because he had a liberty interest in choosing how to die. The court held that his right to administration of a sedative was inextricably linked to his right to remove the ventilator..$^{93}$ In doing so, the court implicitly recognized his right to "die with a maximum of dignity and a minimum of pain." 94

Euthanasia (1992); Lee R. KerR \& Delnetta J. KerR, Natural Death with Dignity: Protecting Your Right to Refuse Medical Treatment (1990); Samuel L. Peluso, To Live and Die with Dignity: A Gume to Living Wills (1991); Timothy E. Quml, Deatr and Dignity: Making Choices and Taking Charge (1993); Robert L. Risley, Death with Dignity: A New Law Permitting Physictan Am-In-Dytng (1989).

87. Tune v. Walter Reed Army Medical Hosp., 602 F. Supp. 1452 (D.D.C. 1985).

88. Id. at 1452.

89. Id. at 1453 (emphasis added).

90. State v. McAfee, 385 S.E.2d 651 (Ga. 1989). For a similar case involving a competent, quadriplegic patient who sought removal of a ventilator and administration of a sedative, see McKay v. Bergstedt, 801 P.2d 617 (Nev. 1990).

91. McAfee, 385 S.E.2d at 651 .

92. Id. at 652 .

93. Id. ("His right to have a sedative ... administered before the ventilator is disconnected is a part of his right to control his medical treatment."). In a similar case, the Nevada Supreme Court reached the same conclusion. McKay, 801 P.2d at 631 ("[A] patient's right to be free from pain at the time the ventilator [or other life support system] is disconnected is inseparable from his right to refuse medical treatment.") (quoting $M c A f e e, 385$ S.E.2d at 652).

94. This language is taken from the Utah Personal Choice and Living Will Act, which says: "[P] ersons should have the clear legal choice to be ... permitted to die with a maximum of dignity and a minimum of pain ...." UTAH CODE ANN. § 75-2-1102(1)(b) (Supp. 1995). Several other state statutes also refer explicitly to peoples' interests in maintaining dignity as a rationale for the right to refuse lifesustaining medical treatment. See, e.g., CAI. HeALTh \& SAFETY CoDE $\$ 7185.5$ (West Supp. 1995); IDaho Code § 39-4502 (1993); 20 PA. Cons. Stat. Ann. § 5402 (Supp. 1994); Tenn. Code AnN. § 3211-102 (Supp. 1994). 
These cases illustrate that a competent, terminally ill patient who refuses life-sustaining medical treatment does so not merely for the sake of refusing treatment, but primarily because the patient has a liberty interest in choosing how to die. Given the fact that the ideal of a good death "has ever been a tradition of Western societies,"95 the liberty interest in choosing how to die can also be characterized as an interest in death with dignity. Since the liberty interest at stake in refusing life-sustaining medical treatment is an interest in death with dignity, the fundamental right to refuse life-sustaining medical treatment is equivalent to a fundamental right to die with dignity by natural PAE.

\section{Patients who are not dependent upon artificial life support.}

The majority in Kevorkian claimed that "the threshold question in this case is whether the [Due Process C]lause encompasses a fundamental right to commit suicide ...."96 But it is misleading to suggest that a competent, terminally ill patient who seeks artificial PAE is asserting a right to commit suicide. No state prohibits a terminally ill person, or any other person, from slashing his/her wrists and bleeding to death, although the person who provides the knife might be subject to criminal penalties. ${ }^{97}$ Nor do any states prohibit a terminally ill person, or any other person, from starving himself to death. If the liberty interest at stake were an interest in committing suicide, then the analysis would be simple. No state imposes an undue burden on the right to commit suicide, because no state prohibits a person from committing suicide.

Similarly, it is misleading to suggest that those who seek artificial PAE are asserting a "right to die." Death is not a right; it is a biological necessity. The Supreme Court long ago recognized that the right at stake in the abortion controversy is not the right to an abortion, but rather the right of a pregnant woman to choose whether to have an abortion. ${ }^{98}$ Similarly, courts should recognize that the right at stake in the physician-assisted suicide controversy is not the right to die, but rather the right of a competent, terminally ill patient to choose how to die. 99

95. NuLAND, supra note 85 , at xvi.

96. People v. Kevorkian, 527 N.W.2d 714, 724 (Mich. 1994) (subsequent history omitted).

97. State laws on assisting suicide vary considerably. For a detailed discussion of state laws on assisting suicide, see Thomas J. Marzen, Mary K. O'Dowd, Daniel Crone \& Thomas J. Balch, Suicide: A Constitutional Right?, 24 DuQ. L. Rev. 1 (1985).

98. Roe v. Wade, 410 U.S. 113, 153 (1973).

99. In Compassion in Dying, the district court relied heavily on the following passage from Casey: "These matters, involving the most intimate and personal choices a person may make in a lifetime, choices central to personal dignity and autonomy, are central to the liberty protected by the Fourteenth Amendment." Compassion in Dying v. Washington, 850 F. Supp. 1454 (W.D. Wash. 1994), aff'd on reh'g, No. 94-35534, 1996 WL 94848 (9th Cir. Mar. 6, 1996) (en banc) (quoting Planned Parenthood of Southeastern Pa. v. Casey, 505 U.S. 833, 851 (1992)). Judge Rothstein argued that choices about how to die are no less central to personal dignity and autonomy than choices about whether to have an abortion. Id. at 1459-60. This note does not place great weight on the abortion analogy, because the link between abortion and PAE is too attenuated to establish a fundamental right to die with dignity on the basis of the established abortion right. Even so, the abortion analogy is instructive in distinguishing between an asserted right to die (which I am not claiming) and a right to choose how to die (which I am claiming). 
Recall the case of Claire Renan. ${ }^{100}$ Her physician's refusal to provide death-inducing medication did not prevent Claire Renan from exercising a supposed "right to die"; she died fairly soon after being diagnosed with cancer.101 Nor did her physician's refusal to provide death-inducing medication prevent her from committing suicide; she could have committed suicide if she chose to do so. ${ }^{102}$ However, the physician's refusal constrained Mrs. Renan's ability to exercise her right to choose how to die. Although she wanted to die with a minimum of pain and a maximum of dignity, she was forced to die with a maximum of pain and a minimum of dignity. ${ }^{103}$ In sum, the right at stake for competent, terminally ill patients who seek artificial PAE is neither a right to commit suicide nor a right to die, but rather a right to choose how to die.

\section{Comparing the two classes of patients.}

Competent patients who are dependent upon artificial life support and who seek natural PAE have a liberty interest in choosing how to die, which I call an interest in death with dignity. Similarly, competent, terminally ill patients who are not dependent upon artificial life support and who seek artificial PAE have an identical liberty interest in choosing how to die. Since the first class of patients has a fundamental right to die with dignity by natural PAE, it follows that the second class of patients also possesses a fundamental right to die with dignity by artificial PAE.

Some claim that the right to natural PAE and the right to artificial PAE are distinguishable, because the former is a "negative right," whereas the latter is a "positive right."104 "Whereas a positive right is a right to be provided with a particular good or service by others, a negative right is a right to be free from some action taken by others." 105 There are two problems with this argument. First, courts have held that the right to natural PAE includes the right to administration of a sedative. ${ }^{106}$ Therefore, the right to natural PAE includes both negative and positive rights. Second, and more important, discussion of negative versus positive rights obscures the fact that the interests of patients who seek natural PAE are indistinguishable from the interests of patients who seek artificial PAE: both have a common interest in choosing how to die. The distinction between negative and positive rights relates not to the interests of the two classes of patients, which are identical, but to the means by which those interests are satisfied.

Given the identity of interests between the two classes of patients, the burden rests with the critics of physician-assisted suicide to advance some ration-

100. See notes 1-4 supra and accompanying text.

101. See Gillick, supra note 1 , at $82-91$.

102. Mrs. Renan was presumably physically capable of committing suicide, since she lived at home without full-time help for some time after the initial cancer diagnosis. See id. at 84-85.

103. See id. at 84-87.

104. Giles R. Scofield, Exposing Some Myths About Physician-Assisted Suicide, 18 Seattre UNIV. L. REV. 473, 478-79 (1995).

105. Id. at 479 n.9 (quoting Tom L. Beauchamp \& James F. Chrdress, Prnnciples of BromediCAL Etrncs 72-73 (4th ed. 1994)).

106. See note 93 supra and accompanying text. 
ale for the claim that the liberty interests of one group are "fundamental," whereas the liberty interests of the other group are not. Critics of physicianassisted suicide have advanced two such rationales. First, they contend, there are significant ethical differences between natural and artificial PAE. Second, they argue, the practice of artificial PAE poses greater risks than the practice of natural PAE. The following two sections address these arguments.

\section{B. Artificial Versus Natural PAE: Ethical Considerations}

Broadly speaking, one can categorize ethical views about voluntary PAE for competent patients ${ }^{107}$ as either "pro-life"108 or "pro-choice."109 The prolife and pro-choice positions agree on three points: (1) Involuntary PAE for a competent patient who wants to live is morally wrong; (2) Voluntary PAE for a depressed, physically healthy individual is also morally wrong; ${ }^{110}$ and (3) It is ethically appropriate to withdraw life support from a competent, terminally ill patient who requests withdrawal of life support. ${ }^{111}$

The next section presents a critique of the pro-life view, using the cases of Martha Tune and Claire Renan, respectively, as exemplars of natural and artificial PAE. The second section presents and defends the pro-choice analysis. Finally, the last section discusses the case of Kenneth Bergstedt to illustrate the superiority of the pro-choice analytical framework in addressing a case that pro-life and pro-choice advocates agree is ethically ambiguous.

\section{The pro-life analysis.}

Pro-life advocates attempt to draw legal and ethical distinctions between cases like Martha Tune's and cases like Claire Renan's by claiming that Claire Renan sought "active" physician assistance, whereas Martha Tune sought "passive" physician assistance. ${ }^{112}$ Withdrawal of Martha Tune's respirator was al-

107. The following discussion of the "pro-life" and "pro-choice" positions focuses on PAE for competent patients. The issue of PAE for incompetent patients raises an entirely different set of ethical problems, which are beyond the scope of this analysis. For a discussion of these problems, see Donahue, supra note 14.

108. For a statement of the pro-life position, see, e.g., Report of the Council on Ethical and Judicial Affairs of the American Medical Association, reprinted in 10 Issues L. \& MED. 91 (1994) thereinafter "AMA Report"]. See also Destro, supra note 15; Dyck, supra note 15. Judicial opinions embodying the pro-life position include Judge Noonan's opinion in Compassion in Dying v. Washington, 49 F.3d 586 (9th Cir. 1995), vacated, No. 94-35534, 1996 WL 94848 (9th Cir. Mar. 6, 1996) (en banc), and Chief Justice Cavanagh's opinion in People v. Kevorkian, 527 N.W.2d 714 (Mich. 1994) (subsequent history omitted).

109. For a statement of the pro-choice position, see, e.g., Harvard Note, supra note 14; Neeley, supra note 14; powell \& Cohen, supra note 14.

110. In the course of her pro-choice argument, Judge Rothstein says: "The court recognizes the tragedy involved when, for example, suicide ends a young life that, with timely and appropriate counseling, could have continued." Compassion in Dying v. Washington, 850 F. Supp. 1454 (W.D. Wash. 1994), aff'd on reh'g, No. 94-35534, 1996 WL 94848 (9th Cir. Mar. 6, 1996) (en banc).

111. The American Medical Association, which is unambiguously pro-life, says: "[T]he principle of patient autonomy requires that physicians must respect the decision to forgo life-sustaining treatment of a patient who possesses decision-making capacity." AMA Report, supra note 108, at 93.

112. Another distinguishing factor to which pro-life advocates sometimes refer is that those who seek artificial PAE have suicidal intent, whereas those who seek natural PAE lack such intent. For a response to this claim, see notes $142-145$ infra and accompanying text. 
legedly passive in two senses: (1) in terms of causality, the disease caused the death; and (2) in terms of the physician's role, the physician passively allowed nature to take its course. In contrast, if Claire Renan's physician had prescribed or administered lethal medication, that medical intervention would have caused Mrs. Renan's death, and thus the physician would have affirmatively acted to end life. ${ }^{113}$

Although this analysis is superficially appealing, it is impossible to distinguish Martha Tune's case from Claire Renan's case on the basis of causality. Suppose that Martha Tune had asked her physician to do everything possible to keep her alive, and he disconnected her respirator against her will. All would agree that the physician caused her death in this case. Yet the mechanics of causality are no different in this hypothetical than in the actual Tune case; in both cases, the act of disconnecting the respirator was a "but-for" cause of death, since Martha Tune would have lived longer if the respirator had not been disconnected. Thus, the proposition that Martha Tune's physician did not cause her death simply means that the pro-life advocate does not hold the physician morally or legally accountable for her death. The pro-life causation analysis is completely circular; pro-life advocates rely on causality to justify an alleged ethical distinction between the Claire Renan case and the Tune case, but the pro-life conception of causality is nothing more than a statement of the prolife ethical position. ${ }^{114}$

Similarly, it is impossible to distinguish the Tune case from Claire Renan's case on the basis of the physician's role. If Martha Tune's physician disconnected her respirator against her will, the pro-life advocate would surely claim that the physician was not merely allowing nature to take its course, but was taking an affirmative act to end her life. Yet the physician's physical act in this hypothetical is no different from the physician's action in the actual Tune case. ${ }^{115}$ Again, the claim that Martha Tune's physician allowed nature to take its course, and did not take an affirmative step to end her life, means only that the pro-life advocate does not hold the physician morally or legally accountable for her death. ${ }^{116}$ As above, the pro-life advocate relies on the physician's role to justify an alleged ethical distinction between the Claire Renan case and the

113. Chief Justice Cavanagh explains the distinction as follows:

[W]hereas suicide involves an affirmative act to end a life, the refusal or cessation of lifesustaining medical treatment simply permits life to run its course, unencumbered by contrived intervention. Put another way, suicide frustrates the natural course by introducing an outside agent to accelerate death, whereas the refusal or withdrawal of life-sustaining medical treatment allows nature to proceed, i.e., death occurs because of the underlying condition.

People v. Kevorkian, 527 N.W.2d 714 (Mich. 1994) (subsequent history omitted).

114. For a similar critique of the pro-life position, see Harvard Note, supra note 14, at 2029-30.

115. In Tune, the court's opinion does not specify whether a physician or someone else disconnected Martha Tune's respirator. The opinion merely states that the court granted Martha Tune's petition to remove her respirator. Tune v. Walter Reed Army Medical Hosp., 602 F. Supp. 1452, 1456 (D.D.C. 1985). Regardless, whoever performed the physical act of removing the respirator, that act is no different in the hypothetical case where Martha Tune wanted to live than it is in the actual case where Martha Tune wanted to die.

116. See Harvard note, supra note 14 , at 2028-29. 
Tune case, but the pro-life conception of the physician's role is nothing more than a statement of the pro-life ethical position.

Hence, the pro-life analysis provides no useful criteria for drawing legal or ethical distinctions between the cases of Martha Tune and Claire Renan, or more broadly, between natural and artificial PAE.

\section{The pro-choice analysis.}

The pro-choice analysis justifies withdrawal of life support from Martha Tune by maintaining that she had a subjective desire to die, which was objectively rational. ${ }^{117}$ Three factors make Ms. Tune's decision objectively rational: ${ }^{118}$ She had an incurable disease; She had a short life expectancy; ${ }^{119}$ and She suffered unbearable pain. ${ }^{120}$

Pro-choice advocates perceive no significant difference between the Tune case and the Claire Renan case. Claire Renan, like Martha Tune, had a subjective desire to die that was objectively rational. She had an incurable disease, 121 a relatively short life expectancy, ${ }^{122}$ and was suffering unbearable pain. ${ }^{123}$ Therefore, the fact that Martha Tune sought natural PAE, whereas Claire Renan sought artificial PAE, is immaterial. 124

Pro-life advocates argue that the very notion that it can ever be objectively rational to choose death over life is morally repugnant, ${ }^{125}$ because this choice

117. The "objective rationality" criterion is implicit in the writings of many pro-choice advocates. E.g., Harvard Note, supra note 14; Neeley, supra note 14; powell \& Cohen, supra note 14. At least one trial court has relied explicitly on a rationality criterion to justify physician-assisted suicide. People v. Kevorkian, No. 93-11482, 1993 WL 603212 (Mich. Cir. Ct. Dec. 13, 1993).

118. All three criteria need not be satisfied in order for a decision to die to be "objectively rational," but all three factors must be considered in assessing the rationality of a decision to die. Some pro-choice advocates present somewhat different criteria. See notes 192-194 infra and accompanying text.

119. Ms. Tune had terminal cancer. Tune, 602 F. Supp. at 1453.

120. The court's opinion in Tune does not state explicitly that she was in great pain, but this is a reasonable inference in light of the available information. See id. at 1453-54.

121. Gillick, supra note 1 , at 84 .

122. The description of Claire Renan's case does not specify the exact time interval between the initial diagnosis of her cancer and her ultimate death. It appears that she lived for about one or two years after the initial diagnosis. See id. at 84-87.

123. One could quibble over the degree of physical pain Claire Renan experienced. Her doctor stated: "When Mrs. Renan became constipated ... she suffered from excruciating pain as she tried to pass a hard stool beyond the constricting tumor mass." Id. at 84-85. But, her doctor also explained, "[S]he really had very little physical pain, except when she was constipated." Id. at 90. Regardless, there is no question that Mrs. Renan suffered great emotional pain, which "arose from her loss of independence, from the shame of her incontinence, from fear of further decay and disintegration." Id. at 90 . The distinction between physical and emotional pain is not particularly significant in cases such as this one, where the emotional pain results directly from the incurable medical condition.

124. In claiming that Martha Tune and Claire Renan both had an "objectively rational" desire to die, I do not suggest that all rational people would prefer an early death under similar circumstances. The term "rational" here means only that rational people could disagree about whether it would be better to live or die under such circumstances.

125.

[F]or the state or one of its agents, judicial or otherwise, to act as a gatekeeper to select who should and who should not be deemed sufficiently competent (or rational or terminal) to die by way of assisted suicide raises obvious troubling questions .... The prospect of dividing the sheep from the goats-those who may die and those who may not-might properly be a role declined based on a profoundly compelling state disinterest in such business. 
implies that some lives are worth more than others. Moreover, the proposition that some lives are worth more than others raises the specter of state-sponsored involuntary euthanasia for those deemed unfit to live. ${ }^{126}$ This criticism is unfounded. From the pro-choice perspective, the proposition that "some lives are worth more than others" is true only in the following limited sense: Sometimes it is ethically right to try to force a person to live against his will (e.g., the classic case of the suicidal teenager); other times it is not ethically right to force a person to live against her will (e.g., Martha Tune). ${ }^{127}$ Nonconsensual killing of a human being, however, is just as antithetical to the principal of free choice as it is to the sanctity of life. Thus, any notion of involuntary euthanasia is diametrically opposed to the ethical precepts of the pro-choice position.

\section{Kenneth Bergstedt-a hard case.}

Kenneth Bergstedt became a quadriplegic at the age of ten as a result of a swimming accident. ${ }^{128}$ Despite his quadriplegia, and total dependence on artificial respiration, Kenneth completed a high school education. ${ }^{129} \mathrm{He}$ "was able to read, watch television, [and] orally operate a computer . . ."130 $\mathrm{He}$ also "wrote poetry and otherwise lived a useful and productive life ...."131 At age thirty-one, Kenneth petitioned the court for an order permitting the removal of his respirator. ${ }^{132}$ Kenneth's decision to remove the respirator was prompted by the impending death of his father, who had been his primary caregiver for the previous decade since his mother had died. ${ }^{133}$ Kenneth did not suffer great physical pain. Rather, his principal affliction was "fear over the quality of his life after the death of his father."134 The trial court granted Kenneth's petition, the respirator was disconnected, and Kenneth died.135

The Bergstedt case is troubling because the three factors cited above as elements of rationality analysis point in different directions. Kenneth's

Marzen, supra note 15 , at 812 (emphasis in original).

126. Marzen says:

The purportedly objective "quality of life" judgments to be made in deciding who should live or die by way of assisted suicide ... have much in common with judgments made by the preWorld War II eugenics movement. . . . The specter is thus raised that if some "quality of life" criteria can be settled upon that warrant voluntary assisted suicide, then the same criteria could be used for other purposes.

Id. at 811 .

127. Although pro-life advocates rightly reject the general proposition that "some lives are worth more than others," they generally agree that there are cases in which it would be ethically inappropriate to try to force someone to live against his will. See, e.g., AMA Report, supra note 108, at 92-93 (acknowledging "the right of patients to self-determination on matters of medical care even if the exercise of that self-determination results in the patient's death").

128. McKay v. Bergstedt, 801 P.2d 617, 620 (Nev. 1990).

129. Id. at 624 .

130. Id. at 620 .

131. Id. at 624 .

132. Id. at 620 .

133. Id. at 624 .

134. Id.

135. The Nevada Supreme Court opinion states that the trial court granted Kenneth's petition, id. at 619 , and that Kenneth died before the appellate process was completed, id. at 619 n.1. I infer from this information that Kenneth died as a result of his respirator being disconnected. 
quadriplegia was incurable, but his medical condition was stable and he could have lived for many years with artificial respiration. ${ }^{136}$ Although the prospect of his father's death undoubtedly caused him great emotional pain, Kenneth might have overcome the grief from losing his father if he had found an appropriate substitute caregiver. ${ }^{137}$ In short, there is no simple answer to the question of whether Kenneth's desire to end his life was objectively rational.

Pro-life advocates contend that the failure of the pro-choice analysis to produce a clear answer in cases like Kenneth Bergstedt's stems from a flaw in the analytic framework. ${ }^{138}$ Their argument is misguided. The analysis fails to produce a clear answer in this case because the Bergstedt case is genuinely a hard case. Any mode of ethical analysis that pretends to offer an easy answer in cases such as this ought to be suspect for that very reason. Conversely, the fact that the pro-choice analysis highlights the complexity of the ethical issues involved demonstrates the superiority of the pro-choice analytic framework.

The shortcomings of the pro-life analysis are evident in Justice Springer's dissenting opinion in Bergstedt. ${ }^{139}$ Justice Springer maintains that removal of Kenneth Bergstedt's respirator was both the "immediate and proximate cause" of his death ${ }^{140}$ and an affirmative act to end his life. ${ }^{141}$ But if removal of Kenneth's respirator was the "immediate and proximate cause of his death," it follows that removal of Martha Tune's respirator was the immediate and proximate cause of her death. If removal of Kenneth's respirator was an affirmative act to end life, it also follows that removal of Martha Tune's respirator was an affirmative act to end life. Thus, if one frames the analysis in terms of causality and the active/passive dichotomy, the two cases become utterly indistinguishable.

Justice Springer anticipates this objection and offers three criteria to distinguish Bergstedt from cases like Martha Tune's. First, he argues that "Bergstedt's explicit and express desire and intention was that of putting an immediate end to his own life."142 But Martha Tune also expressed an intention to end her life. ${ }^{143}$ Virtually every competent patient who has petitioned a court to recognize his right to withdraw artificial life support has intended to end his life; even so, the courts have universally recognized the right to with-

136. Id. at 620 .

137. The majority opinion in Bergstedt states: "It appeared to us that Kenneth needed some type of assurance that society would not cast him adrift in a sea of indifference after his father's passing." Id. at 628. Hence, the court concluded that if Kenneth had survived the appellate process, "it would have been necessary to fully inform him of the care altematives that would have been available to him after his father's death" before permitting removal of his respirator. Id. at 628 .

138. One commentator describes the pro-choice framework as a "house of cards." He says: "The categories relied upon to construct its case- 'rational' suicide, 'terminal condition,' 'unbearable suffering,' . . cannot even be described with any certainty . ..." Marzen, supra note 15, at 826.

139. Justice Springer's opinion is "pro-life" in that he would have refused Kenneth's petition for removal of life support. The majority opinion is "pro-choice" in that the majority approved Kenneth's petition for temoval of life support. See Bergstedt, 801 P.2d 617.

140. Id. at 634 (Springer, J., dissenting).

141. "There was nothing natural about Mr. Bergstedt's death; he killed himself." Id. Similarly, Justice Springer refers to "the direct and active way in which he chose to end his own life." Id. at 635 .

142. Id. at 634 (Springer, J., dissenting).

143. Tune v. Walter Reed Army Medical Hosp., 602 F. Supp. 1452, 1453 (D.D.C. 1985). 
draw treatment. ${ }^{144}$ Thus, the proposition that an express intent to die disqualifies an individual from exercising his right to refuse medical treatment is diametrically opposed to a firmly entrenched judicial consensus. ${ }^{145}$

Second, Justice Springer claims that in Kenneth's case the respirator does not constitute medical treatment.

[A]fter twenty-three years of living and breathing in this machine-aided manner, the whole process becomes something quite more than mere medical treatment.... [T] he ventilator begins as a form of medical treatment but ends up as an integral part of its dependent user. ${ }^{146}$

Therefore, he argues, "[w]ithholding the ventilator was for this man not a withholding of medical treatment, it was the withholding of life itself." 147 This argument has merit. But in making this assertion, Justice Springer has departed from the pro-life analytic framework. The length of time a patient has been connected to a machine is not relevant either to the question of what caused the patient's death, or to the question whether the physician played an active or passive role in ending the patient's life. Justice Springer's argument is persuasive because the length of time Kenneth Bergstedt had lived with his respirator informs an assessment of the objective rationality of his desire to die.

Justice Springer's third criterion is that Kenneth "is not 'terminally ill' or otherwise close to death."148 Justice Springer correctly points to Kenneth's long life expectancy as a factor that distinguishes his case from Martha Tune's. But life expectancy is a criterion that is drawn from the pro-choice analytic framework. ${ }^{149}$ Thus, Justice Springer's only persuasive arguments for distinguishing Bergstedt from the Tune case, and hence his only persuasive arguments in favor of the pro-life position, rely on the pro-choice analytic framework.

The pro-choice and pro-life positions agree that: (1) Natural PAE for Martha Tune is ethical, whereas artificial PAE for a suicidal teenager would be unethical; and (2) The Bergstedt case is much more ambiguous than the Tune case. The pro-choice analysis, by relying on objective medical factors, provides a convincing justification for these shared moral intuitions. The pro-life analysis does not offer a persuasive explanation for these shared moral intuitions. Since the pro-choice analysis provides a convincing justification for our shared moral intuitions, it makes sense to apply the pro-choice analysis to an ethical comparison between natural and artificial PAE. The result is clear: There is no significant ethical distinction between natural and artificial PAE, because the distinction between artificial and natural PAE is unrelated to the

144. Satz v. Perlmutter, 379 So. 2d 359, 360 (Fla. 1980); State v. McAfee, 385 S.E.2d 651, 652 (Ga. 1989); Bergstedt, 801 P.2d at 619 (Nev. 1990); In re Farrell, 529 A.2d 404, 416 (N.J. 1987); Deel v. Syracuse Veterans Admin. Medical Ctr., 729 F. Supp. 231, 234 (N.D.N.Y. 1990).

145. That proposition is also at odds with state living will statutes, none of which makes the absence of an intent to die a precondition for exercising a living will.

146. Bergstedt, 801 P.2d at 634 (Springer, J., dissenting).

147. Id. at 635 .

148. Id. (quoting amicus curiae brief written by Thomas J. Marzen, general counsel for the National Legal Center for the Medically Dependent and Disabled, at 1).

149. See text accompanying notes 117-120 supra. 
objective medical factors that constitute the framework of the only coherent justification for our shared moral intuitions.

\section{Artificial Versus Natural Euthanasia: A Comparative Risk Analysis}

One argument supporting the current legal distinction between artificial and natural euthanasia is the slippery slope argument. Opponents of physician-assisted suicide charge that the "legal machinery initially designed to kill those who are a nuisance to themselves may someday engulf those who are a nuisance to others." 150 There are two classes of patients who might be considered "a nuisance to others": those who are legally incompetent; and those who are legally competent, but extremely dependent on others (and therefore also extremely vulnerable). This section will consider each in turn.

\section{Competent vs. incompetent.}

Critics of physician-assisted suicide support banning the practice because the risk that its legalization would lead to involuntary euthanasia of incompetent patients outweighs any potential benefits for competent patients. ${ }^{151}$ While legalization of physician-assisted suicide may pose some risk to incompetent patients, incompetent patients face a greater risk under existing laws that permit withdrawal of life support. Current living will statutes are specifically designed to provide for withdrawal of life support from incompetent patients. ${ }^{152}$ In contrast, proposals for physician-assisted suicide specifically exclude incompetent patients and provide for terminating the lives only of competent patients. ${ }^{153} \mathrm{~A}$ statute that authorizes PAE for incompetent patients poses a greater risk to incompetent patients than a statute that explicitly authorizes PAE only for competent patients.

With respect to patients who were never legally competent, the worst fears of the opponents of PAE have already been realized. State courts of last resort have considered eight cases involving withdrawal of life support from patients who were never legally competent. In seven of those cases, courts upheld the guardian's right to withdraw the incompetent patient's life-sustaining treatment. ${ }^{154}$ Decisions to withdraw life support from formerly competent patients

150. Yale Kamisar, Some Non-Religious Views Against Proposed "Mercy-Killing" Legislation, 42 MnN. L. REv, 969,976 (1958).

151. Id. at $985-93$.

152. Although a person must be competent to execute a living will, the provisions of the living will generally do not take effect unless and until one becomes incompetent. See, for example, the model declaration in CAL. HEALTH \& SAFETY CODE, § 7186.5(b) (West Supp. 1995) (specifying that a precondition for acting on the advance directive is that "I am no longer able to make decisions regarding my medical treatment.").

153. See, e.g., Oregon Act, supra note 77, § 1.01(6), (11).

154. In re L.H.R., 321 S.E.2d 716, 722-23 (Ga. 1984) (allowing parents to remove the life support of an infant in an irreversible vegetative state and extending the holding to apply to an adult incompetent patient); In re Lawrance, 579 N.E.2d 32, 44 (Ind. 1991) (permitting parents to withdraw artificially provided nutrition from a never-competent 42-year-old woman in a persistent vegetative state); In re P.V.W., 424 So. $2 d$ 1015, 1020 (La. 1982) (allowing an appropriate representative to assert a permanently comatose newbom infant's right to discontinue artificial life support); Care and Protection of Beth, 587 N.E.2d 1377, 1378 (Mass. 1992) (entering a do-not-resuscitate court order for an infant in a 
who have become incompetent can be justified on the grounds that the patient, if competent, would have refused artificial life support. With respect to patients who were never legally competent, however, the argument about what the patient would have chosen, if competent, is a "legal fiction."15s Thus, under the guise of protecting the patient's Fourteenth Amendment liberty interests, ${ }^{156}$ the courts have permitted surrogate decisionmakers to choose involuntary PAE for patients who have never possessed the competence to choose between life and death. This is precisely the nightmare scenario that critics of PAE have long feared. The law has stepped on to the slippery slope and crashlanded at the bottom.

The slide down the slippery slope has occurred even though state legislatures have drawn sharp legal distinctions between natural and artificial PAE. 157 This is not surprising, because no rational relationship exists between the artificial/natural dichotomy and the avowed policy goal of protecting the rights of incompetent patients. If one's policy objective is to protect the rights of incompetent patients, then a rational legal mechanism to achieve that goal is to draw sharp legal distinctions between the rights of competent patients and the rights of incompetent patients. It defies logic, though, to attempt to protect the rights of incompetent patients by means of a legal framework that permits natural $\mathrm{PAE}$ for both competent and incompetent patients, while prohibiting artificial PAE for both competent and incompetent patients.

\section{Voluntary vs. involuntary.}

Consider patients who are legally competent, but extremely dependent on others, and therefore vulnerable to the influence of those who suggest that they choose death over life, even though the patients may not really want to die.158 One could argue that artificial PAE entails a greater risk of undue influence than natural PAE, because living will statutes require patients to make medical

permanent vegetative coma who was a ward of the state); Guardianship of Doe, 583 N.E.2d 1263, 1272 (Mass. 1992) (determining that a profoundly retarded 33-year-old woman in a persistent vegetative state would, if she were capable of making a choice, terminate nasoduodenal feeding and hydration); Superintendent of Belchertown State Sch. v. Saikewicz, 370 N.E.2d 417, 435 (Mass. 1977) (allowing chemotherapy for leukemia to be withheld from a profoundly retarded 67-year-old man); In re Guardianship of L.W., 482 N.W.2d 60, 63 (Wis. 1992) (limiting its holding to persons in persistent vegetative states, and allowing guardian to exercise patient's right to refuse life-sustaining medical treatment, including artificial nutrition and hydration). Only one state court of last resort has ruled against such plaintiffs. Soper v. Storar, 420 N.E.2d 64, 73 (N.Y.) cert. denied, 454 U.S. 858 (1981) (addressing the cases of two incompetent patients and denying the right to deprive lifesaving medical treatment for the patient who was never competent).

155. Guardianship of Doe, 583 N.E.2d 1263, 1268 (Mass. 1992).

156. There may well be good reasons for granting family members and medical professionals the legal right to make life and death decisions on behalf of patients who were never legally competent. However, those rights cannot be founded on a supposed Fourteenth Amendment liberty interest of the never competent patient, because that liberty interest involves a right to choose, and a person who was never competent lacks the capacity to choose.

157. For example, the California Natural Death Act says: "This chapter does not condone, authorize, or approve mercy killing or assisted suicide or permit any affirmative or deliberate act or omission to end life other than to permit the natural process of dying." CaL. HEALTH \& SAFETY COdE $\$ 7191.5(\mathrm{~g})$ (West Supp. 1995). Most other living will statutes include similar provisions.

158. See Kamisar, supra note 13, at 39. 
care decisions before their health fails, whereas proposals for physician-assisted suicide require patients to make decisions while suffering from a terrible physical ailment. ${ }^{159}$ Most people, however, do not execute living wills. They make decisions about withdrawal of life support when they are suffering from a terrible physical ailment as well. ${ }^{160}$ Thus, competent patients who seek artificial $\mathrm{PAE}$ are no more vulnerable to undue influence than are competent patients who become dependent upon artificial life support and lack living wills.

If one's policy objective is to protect legally competent patients who are vulnerable to undue influence, then it is appropriate to draw a sharp legal distinction between voluntary and involuntary euthanasia, and to develop safeguards to ensure that patients who seek PAE do so voluntarily, not under undue influence. Far from being a bulwark against the risk of undue influence, the artificial-natural dichotomy has exacerbated that risk by distracting judges' attention from the critical dividing line between voluntary and involuntary PAE. Although state living will statutes authorize only voluntary euthanasia, judicial decisions have relied on statutory distinctions between natural and artificial euthanasia to legitimate the practice of natural involuntary euthanasia. ${ }^{161}$

Instead of relying on the distinction between natural and artificial PAE to delimit the scope of fundamental rights, the Supreme Court should hold that all competent patients who have a subjective desire to die that is objectively rational have a fundamental right to choose how to die. The "subjective desire" element in this constitutional standard affirms the state's substantial interest in prohibiting involuntary euthanasia. The "objective rationality" element affirms the state's substantial interest in discouraging irrational suicide. Finally, this approach recognizes that the ideal of a good death is deeply rooted in the Western ethical tradition, and that all competent patients with an objectively rational desire to die share a common interest in death with dignity, regardless of whether they seek natural PAE or artificial PAE.

\section{The Permissible Scope of State Regulation}

This Part considers the extent to which states may regulate the practice of PAE without imposing an undue burden ${ }^{162}$ on patients' fundamental rights. The analysis of state regulation is divided into two parts: limitations on the

159. None of the critics of physician-assisted suicide has made this particular argument. The critics warn at length about the dangers of undue influence associated with physician-assisted suicide, but do not compare those dangers with the risk of undue influence associated with the withdrawal of life support. See, e.g., id. at 38-39; Kamisar, supra note 149, at 975-77, 990-93; Marzen, supra note 15, at $811-12$.

160. See, e.g., Deel v. Syracuse Veterans Admin. Medical Ctr., 729 F. Supp. 231 (N.D.N.Y. 1990); Satz v. Perlmutter, 379 So. $2 d 359$ (Fla. 1980); State v. McAfee, 385 S.E.2d 651 (Ga. 1989); McKay v. Bergstedt, 801 P.2d 617 (Nev. 1990); Matter of Farrell, 529 A.2d 404 (N.J. 1987).

161. See, e.g., In re P.V.W., 424 So. 2d 1015, 1022 (La. 1982); Guardianship of Doe, 583 N.E.2d 1263, 1270 (Mass. 1992); Superintendent of Belchertown State Sch. v. Saikewicz, 370 N.E.2d 417, 423 (Mass. 1977).

162. Some argue that "strict scrutiny" is the appropriate standard for evaluating state regulation of PAE. See, e.g., Compassion in Dying v. Washington, 49 F.3d 586, 596 (9th Cir. 1995), vacated, No. 94-35534, 1996 WL 94848 (9th Cir. Mar. 6, 1996) (en banc) (Wright, J., dissenting) (demanding that a statute be narrowly drawn to achieve a compelling state interest). This note applies the undue burden 
class of eligible people, and issues concerning acceptable roles for physicians and nonphysicians.

\section{A. Limiting the Class of Eligible People}

Under Casey, "[a]n undue burden exists, and therefore a provision of law is invalid, if its purpose or effect is to place a substantial obstacle in the path of a woman seeking an abortion before the fetus attains viability."163 Analogously, for our purposes, a provision of law is invalid if its purpose or effect is to place a substantial obstacle in the path of a qualified patient seeking voluntary PAE. But who is a qualified patient?

Part III concluded that the fundamental right to die with dignity extends to all those who have a subjective desire to die that is objectively rational. But since this is a very abstract principle, more concrete guidance is needed. The Oregon Act provides that a competent ${ }^{164}$ adult suffering from a terminal disease, who has voluntarily expressed a wish to die, is eligible for physicianassisted suicide. ${ }^{165}$ It defines a "terminal disease" as "an incurable and irreversible disease that has been medically confirmed and will, within reasonable medical judgment, produce death within six (6) months."166 Thus, the eligibility criteria under the Oregon Act are: (1) competent, (2) voluntary, (3) incurable and irreversible, and (4) short life expectancy. ${ }^{167}$ The following discussion analyzes these four criteria in terms of two sets of considerations. First, is the criterion consistent with the principle of a fundamental right to die with dignity? Second, what are the practical difficulties of distinguishing between those who satisfy the criterion and those who do not?

\section{Competent.}

As a matter of principle, excluding incompetent people from eligibility for $\mathrm{PAE}$ is consistent with the fundamental right to die with dignity. The right to die with dignity is not a "right to die," but rather a right to choose how to die. ${ }^{168}$ An incompetent person is, by definition, incapable of making an informed choice. ${ }^{169}$ Since incompetent people lack the capability to choose how

standard, because the undue burden approach is consistent with the Supreme Court's holding in Cruzan. See notes 37-39 supra and accompanying text.

163. Planned Parenthood of Southeastern Pa. v. Casey, 505 U.S. 833, 878 (1992).

164. The Oregon Act uses the term "capable," rather than "competent." It specifies that a patient is "capable" if he or she has "the ability to make and communicate health care decisions to health care providers." Oregon Act, supra note 77, § 1.01(6).

165. Id. $\$ 2.01$. The Act provides that actions taken in accordance with its terms do not constitute either "assisted suicide" or "active euthanasia." Id. $\$ 3.14$. Nevertheless, this note uses the terms "physician-assisted suicide" and "PAE" to describe the actions authorized by the Oregon Act.

166. Id. $\S 1.01(12)$.

167. The Oregon Act also mandates that a patient must be an adult. Id. § 1.01(11). I assume that the "adult" criterion is not problematic, since most state living will statutes include this criterion as well. See, e.g., Cal. Health \& Safety Code $\$ 7186(\mathrm{~h})$ (West Supp. 1995) (defining "qualified patient").

168. See text accompanying notes $98-103$ supra.

169. The Oregon Act defines "informed decision" as a "decision by a qualified patient." Oregon Act, supra note 77, § 1.01(7). It defines a "qualified patient" as a "capable adult." Id. § 1.01(11). It defines a "capable adult" as one who has the ability to make health care decisions. Id. § 1.01(6). Similar definitional provisions are included in most states' living will statutes. See, e.g., Cal. HeALTH \& 
to die, laws denying them the right to choose are not an undue burden on their fundamental liberty interests.

There are practical difficulties in distinguishing between competent and incompetent people. The difficulty of distinguishing the two groups raises the risk that incompetent patients will be classified as "competent," and will be put to death without their informed consent, under the guise of voluntary euthanasia. Critics of physician-assisted suicide highlight this risk in support of their argument for a ban on physician-assisted suicide. ${ }^{170}$ However, the risk to incompetent patients cannot justify a ban on physician-assisted suicide, because existing laws permitting withdrawal of life support pose a greater risk to incompetent patients than laws permitting physician-assisted suicide. ${ }^{171}$

Even so, under the undue burden standard, states may legitimately develop a variety of safeguards to ensure that patients seeking physician-assisted suicide are indeed competent. For example, the Oregon Act requires two physicians to confirm that a patient is competent before prescribing lethal medication. ${ }^{172}$ Moreover, a patient is ineligible if a court finds that the patient is incompetent. ${ }^{173}$ Such safeguards do not impose an undue burden on a competent person's fundamental right to die with dignity, because they serve "a valid purpose, one not designed to strike at the right itself."174

\section{Voluntary.}

Laws prohibiting involuntary euthanasia, and permitting only voluntary euthanasia, are consistent with the principle of a fundamental right to die with dignity. However, determining when a request for PAE is truly voluntary presents substantial practical difficulties.

The Oregon Act recognizes these difficulties and includes a comprehensive set of safeguards to help ensure that the patient is truly acting voluntarily. The patient must make both a written and oral request for lethal medication; he must then make a second oral request within fifteen days after the initial oral request. At the time of the second oral request, the patient's physician must offer the patient an opportunity to rescind the request. 175 Two physicians must confirm that the patient is acting voluntarily. ${ }^{176}$ If either physician believes that the patient "may be suffering from a psychiatric or psychological disorder, or depression causing impaired judgment," then referral for counseling is required. ${ }^{177}$ The patient's primary physician must inform the patient of available alternatives, "including, but not limited to, comfort care, hospice care and pain

SAFETY CODE § 7186(h) (West Supp. 1995) (defining "qualified patient"); id. § 7186.5(a) (limiting eligibility to individuals of sound mind).

170. See, e.g., Marzen, supra note 15, at 812.

171. See notes 150-156 supra and accompanying text for further elaboration of this point.

172. Oregon Act, supra note 77, § 3.01(1), 3.02 .

173. Id. $\$ 1.01(6)$ (defining "incapable"); $\$ 2.01$ (delineating who is eligible).

174. Planned Parenthood of Southeastem Pa. v. Casey, 505 U.S. 833, 874 (1992).

175. Oregon Act, supra note $77, \S 3.06$.

176. Id. $\S \S 3.01(1)-(3), 3.02$.

177. Id. $\$ 3.03$. 
control."178 The Oregon Act also requires extensive documentation. ${ }^{179}$ The doctor may not write a prescription until 48 hours have elapsed since the time of the patient's written request. ${ }^{180}$ Finally, the doctor must verify that the patient is making an informed decision. ${ }^{181}$ These procedures clearly serve a valid purpose, and do not have the "purpose or effect . . . to place a substantial obstacle in the path"182 of a competent patient seeking to exercise his fundamental right to die with dignity. Therefore, such safeguards pass the undue burden test.

Critics argue that such safeguards do not adequately protect vulnerable patients from undue influence, and that even with such safeguards in place, the law will have the unintended consequence of putting to death many people who do not really wish to die. Therefore, they conclude that physician-assisted suicide should be banned. ${ }^{183}$ Although no safeguards are perfect, the risk of undue influence is no greater in the case of physician-assisted suicide than it is in the case of withdrawal of life support. Thus, that risk cannot justify a complete ban on physician-assisted suicide. ${ }^{184}$

\section{Incurable and irreversible.}

A policy that limits the availability of physician-assisted suicide to people with incurable and irreversible medical conditions, and that excludes those who are physically healthy from the category of eligible people, is consistent with the principle of a fundamental right to die with dignity. Rational people may disagree about the point at which a patient's physical ailments become so debilitating that life is no longer worth living. But a decision by a physically healthy person to commit suicide cannot be considered "rational" in any sense of the term. Only people with an objectively rational desire to die possess a fundamental liberty interest in death with dignity. Thus, excluding physically healthy individuals from eligibility for physician-assisted suicide does not impose an undue burden on anyone's fundamental liberty interests. ${ }^{185}$

178. Id. \$3.01(2).

179. Id. $\$ 3.09$.

180. Id. $\S 3.08$.

181. Id. $§ 3.04$. The Act defines "informed decision" as a decision

that is based on an appreciation of the relevant facts and after being fully informed by the attending physician of: a) his or her medical diagnosis; $b$ ) his or her prognosis; $c$ ) the potential risks associated with taking the medication to be prescribed; $d$ ) the probable result of taking the medication to be prescribed; e) the feasible alternatives, including, but not limited to, comfort care, hospice care and pain control.

Id. $\S 1.01(7)$.

182. Planned Parenthood of Southeastern Pa. v. Casey, 505 U.S. 833, 878 (1992) (defining the undue burden test set forth for abortion laws).

183. See, e.g., Compassion in Dying v. Washington, 49 F.3d 586, $592-93$ (9th Cir. 1995), vacated, No. 94-35534, 1996 WL 94848 (9th Cir. Mar. 6, 1996) (en banc) (emphasizing the problems that would result from a decision allowing physician-assisted suicide); Kamisar, supra note 15, at 38 ("[Ninety] to 100 percent of the [physician-assisted suicide] victims die while they have a diagnosable psychiatric illness.").

184. See notes $139-157$ supra and accompanying text.

185. This conclusion comports with the law goveming refusal of life-sustaining medical treatment. For example, living will statutes generally limit the right to refuse life-sustaining medical treatment to those with incurable and irreversible medical conditions. See, e.g., Cal. Health \& SAfrty 
It would be a mistake, though, to conclude that everyone with an incurable and irreversible medical condition is automatically eligible for physician-assisted suicide. Diabetes is often incurable and irreversible, but a decision to commit suicide merely because one has diabetes could not be considered "rational."186 Only those with an objectively rational desire to die have a fundamental right to die with dignity. Therefore states may, consistent with the undue burden standard, impose additional limitations on the class of eligible people by excluding patients with incurable and irreversible medical conditions who lack an objectively rational desire to die. This note shall consider such additional limitations below. ${ }^{187}$

Before continuing, however, it is necessary to respond to arguments about the practical difficulties involved in determining whether a particular medical condition is incurable and irreversible. Two such arguments exist: (1) Doctors might misdiagnose the disease, concluding that it is incurable when it is in fact curable; 188 and (2) A disease that is incurable today might be curable tomorrow. ${ }^{189}$ The Oregon Act addresses these concerns by requiring two physicians to agree that the patient's condition is incurable and irreversible, thus reducing the possibility of error. ${ }^{190}$ In light of concerns about faulty diagnoses, this requirement clearly serves a valid purpose and does not impose an undue burden on the patient's fundamental rights.

Critics contend that the state's legitimate interest in ensuring that patients satisfy the "incurable and irreversible" criterion warrants additional safeguards. While some further safeguards may be useful, ${ }^{191}$ concerns about misdiagnoses and miracle cures are no more salient in the case of physician-assisted suicide than in the case of refusal of life-sustaining treatment. Since the state's interest in ensuring that patients satisfy the "incurable and irreversible" criterion is not sufficiently compelling to justify an outright ban on withdrawal of life support, that interest is also not sufficiently compelling to justify an outright ban on physician-assisted suicide.

CODE §§ 7186(h), (j) (West Supp. 1995); see also Cruzan v. Director, Mo. Dep't of Health, 497 U.S. 261,280 (1990) ("We do not think a State is required to remain neutral in the face of an informed and voluntary decision by a physically able adult to starve to death.").

186. Marzen cites the example of a diabetic to illustrate the difficulty of defining a "terminal condition." Marzen, supra note 15, at 815 . While I disagree with his conclusion, the example is nevertheless instructive.

187. See notes 191-201 infra and accompanying text.

188. " '[Пncurability of a disease is never more than an estimate based upon experience, and how fallacious experience may be in medicine only those who have had a great deal of experience fully realize.' " Kamisar, supra note 150, at 997 (quoting I. Phillips Frohman, Vexing Problems in Forensic Medicine: A Physician's View, 31 N.Y.U. L. Rev. 1215, 1216 (1956)).

189. Id. at 999.

190. "Incurable and irreversible" is included within the definition of "terminal disease." Oregon Act, supra note $77, \S 1.01(12)$. The attending physician must determine that the patient has a terminal disease. Id. \$ 3.01(1). A consulting physician must confirm the attending physician's diagnosis in writing. Id. $\S 3.02$.

191. One can readily imagine additional safeguards that would satisfy the undue burden test. For example, one or both of the physicians might be required to be a specialist with respect to the particular disease that the patient is diagnosed as having. 


\section{Short life expectancy.}

Advocates of physician-assisted suicide face a difficult dilemma when they attempt to distinguish between patients who have a rational desire to die and therefore are eligible for physician-assisted suicide and patients who possess an irrational desire to die and are ineligible. In addition to the preceding criteria (competent, voluntary, incurable and irreversible), two other criteria may be used to distinguish the rational from the irrational: short life expectancy and severe pain. Bearing in mind these two criteria, judges and legislators can consider five possible positions to determine what class of people qualify for physician-assisted suicide: (1) Competent patients with an incurable and irreversible medical condition need not satisfy either additional criterion to be eligible for physician-assisted suicide; (2) One must have a short life expectancy to be eligible; ${ }^{192}$ (3) One must have severe pain to be eligible;193 (4) One must have both a short life expectancy and severe pain to be eligible;194 or (5) One must have either a short life expectancy or severe pain to be eligible.

The first option-requiring only that a competent patient have an incurable and irreversible condition, regardless of his life expectancy or the degree of pain associated with that condition-is unsatisfactory. Such a requirement does not distinguish between conditions such as diabetes and terminal cancer; it would grant to both sets of afflicted patients equal rights to end life, despite the profound difference between the effects of these conditions on the patients' lives. Although this option does not impose an undue burden on anyone's fundamental right to die with dignity, it fails on policy grounds because it gives insufficient weight to the state's interest in preserving life.

The second option-requiring that a competent patient have a short life expectancy to be eligible for physician-assisted suicide-imposes an undue burden on the rights of patients with extremely painful, incurable "but not imminently terminal, progressive illnesses such as ALS or multiple sclerosis."195 If a patient has a life expectancy that can be measured in years, rather than months, but also has a reasonable expectation of experiencing constant agonizing pain, and becoming so debilitated that it will be impossible to engage in any "normal" activities, it would surely be "rational" for such a patient to prefer an

192. This is the position reflected in the Oregon Act. Oregon Act, supra note 77, $\S 1.01(12)$ (defining an incurable and irreversible disease as one that would produce death in six months). The district court in Compassion in Dying also implicitly adopted this position. In that opinion, Judge Rothstein's eligibility criteria were: (1) adult; (2) competent; (3) voluntary; and (4) terminally ill. Compassion in Dying v. Washington, 850 F. Supp. 1454, 1455-62 (W.D. Wash. 1994), aff'd on reh'g, No. 9435534, 1996 WL 94848 (9th Cir. Mar. 6, 1996) (en banc). Judge Rothstein did not define "terminally ill." Most definitions, however, include the elements of incurability and short life expectancy, but exclude the requirement of severe pain.

193. This is the position advocated by Dr. Timothy Quill. "The patient must have a condition that is incurable, and associated with severe, unrelenting suffering." QunL, supra note 86, at 162.

194. One of the dissenters in Kevorkian says: "I would hold . . . that [the Michigan law] violates the Due Process Clause insofar as it bars a competent, terminally ill person facing imminent, agonizing death from obtaining medical assistance to commit suicide." People v. Kevorkian, 527 N.W.2d 714, 746 (Mich. 1994) (Levin, J., dissenting) (subsequent history omitted).

195. QuILI, supra note 86, at 162. 
early death over continued life. ${ }^{196}$ Since all competent patients with an objectively rational desire to die have a fundamental right to die with dignity, the Oregon Act is unconstitutional insofar as it prohibits physician-assisted suicide for patients with extremely painful and incurable, but not imminently terminal, illnesses. ${ }^{197}$

The third option-requiring that a competent patient have severe pain to be eligible-also presents problems. States have experience in addressing the practical problems associated with determining who meets the other criteria discussed above (competent, voluntary, incurable and irreversible, short life expectancy), because all those criteria are embodied in living will statutes. ${ }^{198}$ In contrast, states have little experience addressing the practical problems associated with determining who satisfies the "severe pain" criterion. Indeed, that criterion is not embodied in any living will statute.

If the law provides that only those patients with severe current pain are eligible, it would arguably impose an undue burden on the rights of patients whose only "pain" is the anxiety of knowing, based upon medical diagnosis, that they will experience severe pain in the near future. If the law provides that only those patients with severe physical pain are eligible, it would arguably impose an undue burden on the rights of patients whose only "pain" is the indignity of being incontinent, confined to bed, and completely dependent upon others. ${ }^{199}$ But if the law defines "severe pain" in a way that accommodates the interests of all these patients, then the "severe pain" criterion would not be useful in discriminating between patients with a rational desire to die and those with an irrational desire to die.

The fourth option-requiring that a competent patient have both a short life expectancy and severe pain to be eligible for physician-assisted suicide-is not satisfactory because it suffers from all the flaws of both the second and third options. That is, patients suffering from a painful, nonterminal condition would continue to suffer, and the state would still face practical difficulties in applying the "severe pain" criterion.

The fifth option is the most promising-requiring that a competent patient have either a short life expectancy or severe pain to be eligible for physicianassisted suicide. But, in light of the problems associated with the "severe pain" criterion, this option should be recast in the following terms. First, the patient would be deemed eligible only if he satisfied all the other eligibility criteria discussed above (competent, voluntary, incurable and irreversible), and two

196. In making this claim, I do not intend to suggest that all rational people would prefer an early death under these circumstances. The term "rational" here means only that rational people could disagree about whether it would be better to live or die under such circumstances. Granted, many rational people would undoubtedly prefer to continue living, no matter how bleak the situation.

197. The Oregon Act excludes patients with a life expectancy of more than six months. Oregon Act, supra note $77, \S 1.01(12)$.

198. Not every living will statute incorporates all these criteria. However, most living will statutes incorporate most of these criteria. See, e.g., Cal. Health \& SafeTy CODE $\$ 7186.5$ (a) (West Supp. 1995) ("of sound mind"); id. § 7186.5(b) ("voluntarily"); id. \& 7186(j) ("incurable and irreversible," "result[ing] in death within a relatively short time").

199. See note 122 supra (describing Claire Renan's condition). 
physicians certified that, in their professional medical judgment, the patient had a life expectancy of less than six months. ${ }^{200}$ Second, in lieu of a "severe pain" requirement, a competent patient with an incurable and irreversible medical condition who did not pass the life expectancy test would have the option of petitioning a court to obtain a judgment that his desire to die was rational. Judgments in favor of patients would not be subject to appeal. Although the requirement for judicial action would undoubtedly impose a burden on patients who did not pass the life expectancy test, this would not be an undue burden, in light of the state's substantial interest in limiting the class of eligible patients to those with a rational desire to die. ${ }^{201}$

\section{B. Other Issues}

Having defined the class of eligible people, two other issues merit consideration. First, does the stipulation that physicians may prescribe, but may not administer, lethal medication impose an undue burden on the fundamental right to die with dignity? Second, do laws prohibiting people other than physicians from assisting a suicide impose an undue burden on the fundamental right to die with dignity?

\section{Prescribing vs. administering.}

The Oregon Act authorizes physicians to write a prescription for lethal medication, but prohibits physicians from actually administering a lethal injection. ${ }^{202}$ One rationale for this prohibition is to provide an additional safeguard to help ensure that the patient is acting voluntarily. ${ }^{203}$ Thus, the prohibition against administering medication is rationally related to a legitimate state interest.

Even so, this provision of the Oregon Act imposes an undue burden on the fundamental rights of patients who cannot self-administer lethal medication.

200. The six-month figure is taken from the Oregon Act, supra note $77, \S 1.01(12)$. As a constitutional matter, states would be free to use a different number, or to adopt any of the life expectancy formulations embodied in state living will statutes-e.g., a medical condition that will "within reasonable medical judgment, result in death within a relatively short time." CAL. HEALTH \& SAFETY CODE, $\$ 7186(j)$ (West Supp. 1995). Arguments about the practical difficulties associated with determining who satisfies this criterion essentially parallel the arguments related to incurability. See notes 188-191 supra and accompanying text. In light of the potential for misdiagnosis, a requirement that two physicians concur in the diagnosis would pass the undue burden test. However, the practical difficulties associated with evaluating life expectancy cannot justify an absolute prohibition against physician-assisted suicide.

201. This proposed procedure is similar, in many respects, to the current state of the law with respect to refusal of life-sustaining treatment. State living will statutes explicitly authorize withdrawal of treatment from patients who have a short life expectancy. Judicial decisions have extended this right to numerous patients who fail to satisfy the life expectancy criterion. See notes $42-48$ supra and accompanying text.

202. "Nothing in this Act shall be construed to authorize a physician or any other person to end a patient's life by lethal injection." Oregon Act, supra note 77, § 3.14 .

203. There was also a tactical political rationale for this provision. Previous voter initiatives to legalize physician-assisted suicide in California and Washington failed to obtain the required majority, in part because the ballot measures did not distinguish between prescribing and administering lethal medication. Timothy Egan, Suicide Law Placing Oregon on Several Uncharted Paths, N.Y. TMES, Nov. 25, 1994, at A1, B14. 
[S]uppose that a person is unable to swallow the barbiturates that will bring about death .... If the right to control the time and manner of one's deaththe right to shape one's death in the most humane and dignified manner one chooses-is well founded, how can it be denied to someone simply because she is unable to perform the final act by herself? ${ }^{204}$

The prohibition against lethal injection presents an additional problem. Taking medication by mouth is far less effective than lethal injection; in many cases oral ingestion of barbiturates does not result in death, but in protracted suffering. ${ }^{205}$ Therefore, Oregon's prohibition against lethal injection also imposes an undue burden on some patients who are capable of swallowing.

\section{Assisted suicide by nonphysicians.}

If the Oregon Act becomes law, it will remain a crime in Oregon for anyone other than a physician to assist a suicide. ${ }^{206}$ Critics have argued that it is irrational to limit the class of people eligible to assist a suicide to physicians only. They contend that the practice of assisted suicide is fundamentally incompatible with medical ethics. Therefore, they conclude, "the medical profession is, in fact, the last class that ought to be granted" the right to assist a suicide. ${ }^{207}$

This argument proceeds from the mistaken premise that the right at issue is a general right to die, rather than a more specific right to die with dignity. If one claimed a fundamental right to die, then it would be difficult to justify any prohibition against assisted suicide, either by physicians or nonphysicians. But this note has argued not for a fundamental right to die, but rather for a fundamental right to die with dignity. Furthermore, there is a class of competent patients suffering from incurable medical conditions who want to die with dignity, but who require physician assistance to do so. ${ }^{208}$ For such people, the general prohibition against assisted suicide by nonphysicians does not impose an undue burden on their fundamental right to die with dignity, provided that there is a legal option to obtain physician assistance. Moreover, the general prohibition against assisted suicide by nonphysicians is fully justified by the state's substantial interest in protecting life.

204. Kamisar, supra note 13, at 35 (contending that the Supreme Court should not recognize a right to physician-assisted suicide, because the right, once recognized, is not subject to any rational limitation).

205. Derek Humphry, Oregon's Assisted Suicide Law Gives No Sure Comfort to Dying, N.Y. TnEs, Dec. 3, 1994, at A22.

In a controlled study in the Netherlands, 90 people were given, at their request, nine grams of barbiturate by mouth. Sixty-eight died quickly - within two hours. The rest lingered as long as four days; in 15 instances the doctor gave a lethal injection because the oral drugs were Id. causing protracted suffering to the patient, the family and himself.

206. OR. REv. STAT. § 163.125 (1990) ("Criminal homicide constitutes manslaughter in the second degree when ... [a] person intentionally causes or aids another person to commit suicide.").

207. Marzen, supra note 15 , at 825.

208. See notes 100-103 supra and accompanying text. 


\section{Conclusion}

Before long, the Supreme Court will probably reconsider the right to PAE. In doing so, the Court must choose among three options: (1) No one, not even those who are dependent upon artificial life support, has a fundamental right to choose how to die; (2) All competent patients with a subjective desire to die that is objectively rational have a fundamental right to choose how to die; and (3) Those who are dependent upon artificial life support have a fundamental right to die with dignity by natural PAE, but those who are not dependent upon artificial life support do not have a fundamental right to die with dignity by artificial PAE.

The first option is no longer tenable. A competent, terminally ill patient has a fundamental right to refuse life-sustaining medical treatment because: (1) The Supreme Court's holding in Cruzan is consistent with the view that this is a fundamental right; (2) The common law right to refuse unwanted medical treatment is deeply rooted in this nation's history and tradition; (3) In response to recent advances in medical technology, state and federal courts and state legislatures have expanded that traditional common law right to encompass the right of a competent, terminally ill patient to refuse life-sustaining medical treatment; and (4) Every federal court and state court of last resort that has considered the issue agrees that the right of a competent, terminally ill patient to refuse life-sustaining medical treatment outweighs countervailing state interests. Arguments to the contrary fail, because they either: (1) fail to distinguish the refusal of life-sustaining medical treatment from suicide; or (2) adopt an exceedingly narrow view of the scope of fundamental rights, which is inconsistent with the dominant approach to substantive due process jurisprudence embodied in the Casey joint opinion.

The third option is equally untenable. The liberty interests of competent, terminally ill patients who seek natural PAE are indistinguishable from the liberty interests of competent, terminally ill patients who seek artificial PAE; both have a common interest in choosing how to die. Moreover, there is no significant ethical distinction between natural and artificial PAE. The artificial/natural dichotomy is unrelated to the objective medical factors that constitute the framework of the only coherent justification for our shared moral intuitions. Finally, there is little, if any, rational relationship between the artificial/natural dichotomy and the avowed policy objectives of protecting incompetent patients from involuntary euthanasia, and protecting competent, vulnerable patients from undue influence. In fact, the practice of natural PAE poses a greater risk to incompetent patients than does the practice of artificial PAE, and the risks to competent patients are comparable in the two cases.

The Supreme Court should adopt the second option and hold that all competent patients with a subjective desire to die that is objectively rational have a fundamental right to choose how to die. The "subjective desire" element in this constitutional standard affirms the state's substantial interest in prohibiting involuntary euthanasia. The "objective rationality" element affirms the state's substantial interest in discouraging irrational suicide. Finally, this approach 
recognizes that the ideal of a good death is deeply rooted in the Western ethical tradition, and that all competent patients with an objectively rational desire to die share a common interest in death with dignity, regardless of whether they seek natural PAE or artificial PAE.

Even assuming a fundamental right to choose how to die, states may still enact restrictive legislation to promote their interest in preserving life. States may limit the class of people eligible for voluntary PAE to include only competent patients with incurable and irreversible medical conditions. States may also impose an additional eligibility criterion of a short life expectancy, provided that there is a judicial bypass procedure for competent patients with an incurable and irreversible medical condition who do not satisfy the life expectancy criterion. States may devise a variety of safeguards to help ensure that patients are acting voluntarily, and that the preceding eligibility criteria are satisfied. Finally, states may prohibit people other than physicians from assisting suicide, but states may not prohibit physicians from administering a lethal dose of medication to a qualified patient. 
HeinOnline -- 48 Stan. L. Rev. 974 1995-1996 